\title{
Peroxisome Proliferator-Activated Receptors (PPAR) $\gamma$ Agonists as Master Modulators of Tumor Tissue
}

\author{
Daniel Heudobler ${ }^{1}$, Michael Rechenmacher ${ }^{1}$, Florian Lüke ${ }^{1}$, Martin Vogelhuber ${ }^{1}$, \\ Tobias Pukrop ${ }^{1}$, Wolfgang Herr ${ }^{1}$, Lina Ghibelli ${ }^{2}$, Christopher Gerner ${ }^{3}{ }^{\mathbb{D}}$ and \\ Albrecht Reichle ${ }^{1, *(D)}$ \\ 1 Department of Internal Medicine III, University Hospital Regensburg, Hematology and Oncology, \\ 93042 Regensburg, Germany; daniel.heudobler@ukr.de (D.H.); michael.rechenmacher@kr.de (M.R.); \\ florian.lueke@ukr.de (F.L.); martin.vogelhuber@ukr.de (M.V.); tobias.pukrop@ukr.de (T.P.); \\ wolfgang.herr@ukr.de (W.H.) \\ 2 Department Biology, Universita' di Roma Tor Vergata, 00173 Rome, Italy; ghibelli@uniroma2.it \\ 3 Institut for Analytical Chemistry, Faculty Chemistry, University Vienna, A-1090 Vienna, Austria; \\ christopher.gerner@univie.ac.at \\ * Correspondence: albrecht.reichle@ukr.de
}

Received: 28 September 2018; Accepted: 6 November 2018; Published: 9 November 2018

\begin{abstract}
In most clinical trials, thiazolidinediones do not show any relevant anti-cancer activity when used as mono-therapy. Clinical inefficacy contrasts ambiguous pre-clinical data either favoring anti-tumor activity or tumor promotion. However, if thiazolidinediones are combined with additional regulatory active drugs, so-called 'master modulators' of tumors, i.e., transcriptional modulators, metronomic low-dose chemotherapy, epigenetically modifying agents, protein binding pro-anakoinotic drugs, such as COX-2 inhibitors, IMiDs, etc., the results indicate clinically relevant communicative reprogramming of tumor tissues, i.e., anakoinosis, meaning 'communication' in ancient Greek. The concerted activity of master modulators may multifaceted diversify palliative care or even induce continuous complete remission in refractory metastatic tumor disease and hematologic neoplasia by establishing novel communicative behavior of tumor tissue, the hosting organ, and organism. Re-modulation of gene expression, for example, the up-regulation of tumor suppressor genes, may recover differentiation, apoptosis competence, and leads to cancer control—in contrast to an immediate, 'poisoning' with maximal tolerable doses of targeted/cytotoxic therapies. The key for uncovering the therapeutic potential of Peroxisome proliferator-activated receptor $\gamma(\operatorname{PPAR} \gamma)$ agonists is selecting the appropriate combination of master modulators for inducing anakoinosis: Now, anakoinosis is trend setting by establishing a novel therapeutic pillar while overcoming classic obstacles of targeted therapies, such as therapy resistance and (molecular-)genetic tumor heterogeneity.
\end{abstract}

Keywords: anakoinosis; communicative reprogramming; nuclear transcription factors; metronomic low-dose chemotherapy; glitazones; all-trans retinoic acid; COX-2 inhibitor; master modulators; undruggable targets; therapy pillar; peroxisome proliferator-activated receptors (PPARs); energy homeostasis; metabolic regulations; organ cross-talk; cancer and reprogramming of energy metabolism; systems biology

\section{Introduction}

Peroxisome-proliferator-activated receptors (PPARs) line up in the group of nuclear receptors and encompass three receptors PPAR $\alpha, \operatorname{PPAR} \gamma$, and PPAR $\delta$, which concertedly and multifaceted have impact on regulating tumor growth [1]. From metabolic disease, the resolution of insulin resistance 
by PPAR $\gamma$ and combined PPAR $\alpha / \gamma$ agonists, as well as long-term outcome in patients with type II diabetes, we learned a lot on simultaneous PPAR $\alpha / \gamma$ stimulation. A specific PPAR $\gamma$ agonist has been withdrawn from the market, as rosiglitazone was associated with a significant increase in the risk of death from cardiovascular causes, from myocardial infarction [2]. The beneficial effects of the dual $\operatorname{PPAR} \alpha / \gamma$ agonist, pioglitazone, namely the reduction of mortality, including non-fatal myocardial infarction and stroke in patients with type 2 diabetes who are at high risk concerning macro-vascular events, shed light on the multi-level concerted activity profile of PPAR $\alpha$ and PPAR $\gamma$ in diabetes [3]. Particularly, these clinical trials in patients with diabetes type II highlight the striking anti-inflammatory component of PPAR $\alpha$. The initial hypothesis that efficacious anti-inflammatory therapy may also control advanced cancer could be confirmed by introducing pioglitazone in treatment of refractory metastatic cancer $[4,5]$. From pre-clinical data, the appropriate PPAR $\alpha$ agonist for cancer treatment has to be defined, yet [1].

Nuclear receptors (NRs) encompass a huge heterogeneous group of ligand-controlled transcription factors, endocrine, orphan and adopted receptors [6]. Schedules for cancer treatment using ligand-mediated modulation of NRs are well-established, particularly the blockade of endocrine NRs in prostate and breast cancer or the stimulation with high-dose glucocorticoids in lymphoma or multiple myeloma [7-9]. In contrast, adopted NR agonists only hesitantly found their way into cancer treatment, e.g., retinoid X receptor (RXR) and retinoic acid receptor (RAR) receptor agonists for treatment of T-cell lymphoma and promyelocytic leukemia, respectively $[10,11]$.

A further NR agonist, pioglitazone, a dual peroxisome-proliferator-activated receptor (PPAR) $\alpha / \gamma$ agonist, is now starting to blaze the trail for therapy of metastatic tumor diseases and it will be discussed in more detail [12].

Therapeutically intended stimulation of adopted NRs for tumor control is in striking methodologic contrast to blocking endocrine NRs with antagonists or inducing direct cytotoxicity with high-dose glucocorticoids, opens a novel view on tumor pathophysiology, and finally, implies a change of treatment paradigms [13].

Following oncogenic events, dysregulated homeostatic pathways and transcription factors in tumor tissues are communication-technically accessible via endocrine, orphan, and adopted NR agonists or more general, via master modulators, a term summarizing regulatory active, less toxic drugs administered at regulatory active dose levels [12,14]. 'Master modulators' of tumors, i.e., transcriptional modulators, metronomic low-dose chemotherapy, epigenetically modifying agents, protein binding pro-anakoinotic drugs, such as COX-2 inhibitors, IMiDs, etc., are aiming at attenuation of cancer-associated hallmarks or at establishing novel biologic hallmarks linked to tumor control. 'Master modulators' deploy therapeutic activity via regulatory accessible structures, functions, and hubs in tumor tissue, thereby e.g., reestablishing differentiation and apoptosis competence (Table 1) [12].

NRs are involved in regulating multifold biologic processes in normal and tumor tissue [15-17]. Clinical trials have shown that 'normalization' of dysregulated transcription factors with NR agonists belongs to a pivotal, clinically relevant concept, and it finally constitutes a novel therapeutic pillar for treatment of (refractory) metastatic cancer [12]. However, in relation to the multitude of orphan and adopted nuclear receptors, the clinical impact of corresponding nuclear receptor agonists has not been nearly exploited in the clinical setting.

Multi-level activity profiles on single cell compartments, tissues, or the whole organism are characteristic for NR agonists [12]. Multifaceted clinically beneficial changes in tumor behavior are based on the ubiquitous availability of NRs in tissues. The distribution of single NRs, however, is tissue-specifically varying, implicating tissue-, and as shown, cancer-specific activity profiles $[6,18]$. Moreover, the kind of ligand, i.e., a synthetic or natural hormone and/or lipophilic drug, additionally, has major impact on multi-level outcome $[19,20]$. 
Table 1. Explanation of communication-associated terms.

\begin{tabular}{|c|c|}
\hline Communication-Associated Terms & Explanation \\
\hline Anakoinosis & $\begin{array}{l}\text { Anakoinosis is a novel paradigm for cancer treatment based on a key role for } \\
\text { communicative reprogramming of tumor systems. Building on a systems biology } \\
\text { approach to cancer, anakoinosis utilizes a range of non-cancer and cancer drugs in } \\
\text { combination to treat advanced tumor disease, such as pioglitazone. In contrast to } \\
\text { standard therapies, anakoinosis protocols are characterized by low toxicity and a good } \\
\text { safety profile, with encouraging responses in a number of clinical trials to date. The use } \\
\text { of drug repurposing, that is the use of non-cancer drugs as cancer treatments, is } \\
\text { especially a notable feature of this approach. }\end{array}$ \\
\hline $\begin{array}{l}\text { Pro-anakoinotic therapeutic tools } \\
\text { (examples) }\end{array}$ & $\begin{array}{l}\text { Transcriptional modulators, nuclear receptor agonists and antagonists, metronomic } \\
\text { low-dose chemotherapy, cyclooxygenase-2 inhibitors, IMiDs, arsenic trioxide, } \\
\text { liposomal encapsulated small oligonucleotide encoding small activating RNAs, etc. }\end{array}$ \\
\hline Metronomic tumor therapy & $\begin{array}{l}\text { Metronomic tumor therapy may be defined as the frequent administration of } \\
\text { (repurposed) drugs at doses significantly below the maximum tolerated dose with no } \\
\text { prolonged drug-free breaks, or as the minimum biologically effective dose of an agent } \\
\text { given as a continuous dosing regimen with no prolonged drug-free breaks that still } \\
\text { leads to anti-tumor activity. }\end{array}$ \\
\hline Rationalizations & $\begin{array}{l}\text { Describe the physical organization of tumor-associated normative notions (e.g., } \\
\text { hallmarks of cancer); are to some degree histology- and genotype-independent; may be } \\
\text { re-directed and reorganized by anakoinosis. }\end{array}$ \\
\hline Metabolism of evolution & $\begin{array}{l}\text { The sum of extrinsically, i.e., therapeutically, and intrinsically inducible evolutionary } \\
\text { processes within the tumor environment (tumor stroma, hosting organ, distant organ } \\
\text { sites). }\end{array}$ \\
\hline Modularity & $\begin{array}{l}\text { Modularity describes the degree and specificity to which systems' objects, i.e., cells, } \\
\text { pathways, molecules, therapeutic targets etc. may be communicatively rededicated by } \\
\text { anakoinosis. }\end{array}$ \\
\hline Validity and denotation & $\begin{array}{l}\text { Validity of systems objects, functions and hubs: Availability on demand at distinct } \\
\text { systems stages; denotation: Current functional impact at a distinct systems stage, e.g., } \\
\text { of potentially tumor-promoting pathways. In the bio-world, presence and functioning } \\
\text { of an object (e.g., an enzyme), respectively. }\end{array}$ \\
\hline
\end{tabular}

The ligand induced physical activity profile of NRs is dependent on multifold system-specific co-variables [21]. Their receptor and non-receptor mediated activity profile may explain and provide an insight in the multiplicity of biologic effects based on the predominantly regulatory and coordinating cell and tissue activities of NRs [22-24]. Therefore, interpretation and prediction of biologic outcome on the different observation levels within an organism is difficult and only accessible by application of novel technologies for monitoring ligand mediated biologic activities while treating metastatic tumors with nuclear receptor agonists.

Ligand induced structural changes of NRs facilitate binding at nuclear receptor response elements (NRREs) across the genome, but also the recruitment of co-regulators and interaction with other transcription factors, which may be again context-dependently activated or inhibited [25-27]. The obvious communication guided activity profile of NRs explicates why biologic read-outs may be contradictory depending on respective boundary conditions or systems stages, particularly in diseased organs [12].

When considering the context-dependent regulatory activity profile of NRs and the fact that cancer is constituted by complex dysregulation of transcription factors and homeostatic pathways, the following question arises: what kind of paradigms must be assumed for introducing NR agonists as attractive clinical targets, here, in particular, the $\alpha$ and $\gamma$ variant of the peroxisome-proliferator-activated receptors (PPARs)? Secondly, may be the novel treatment approach, including agonists of nuclear receptors, universally applicable for treatment of metastatic, and refractory cancer and hematologic neoplasia?

\section{Peroxisome Proliferator-Activated Receptor $\gamma(\operatorname{PPAR} \gamma) /$ Cyclooxygenase-2 (COX-2) Expression in Tumors}

Modulating COX-2 activity influences the local availability of PPAR ligands. Therefore, COX-2 indirectly modulates PPAR activity. Though acting on different signaling pathways, COX-2 and 
PPAR $\gamma$ modulate common molecular targets. Thus, COX-2 and PPAR $\gamma$ may concertedly inhibit cancer development [28]. Thereby, COX-2 inhibitors may act as partial PPAR $\gamma$ agonists [29], or PPAR $\gamma$ agonists as partial COX-2 inhibitors and suppressors of PGE2 synthesis [30,31].

Because of the close interaction of COX-2 and PPAR $\gamma$, the differential expression in many human tumors, and the emerging possibilities to use them as targets for tumor therapy, we studied the correlation of PPAR $\gamma /$ COX-2 immunoreactivity with tissue microarrays (TMA) in a broad spectrum of histologic tumor types in comparison to normal tissue. In malignant melanoma, we focused on the correlation between clinic-pathologic features and outcome of patients with malignant melanoma (MM) [18].

TMA consisted of normal and tumor tissues $(n=3448)$ from 47 organs and tissue entities, including skin neoplasms ( $n=323)$ of melanocytic (MM, benign nevi) and non-melanocytic origin (squamous cell carcinomas, basal cell carcinomas, Kaposi sarcomas, histiocytomas, capillary hemangiomas, sebaceous adenomas) [18].

COX-2 and PPAR $\gamma$ expression assays showed differential expression in almost every tissue type as well as in normal vs. neoplastic tissue: i.e., a continuous increase in COX2 expression from prostatic hyperplasia to prostatic intraepithelial neoplasia (PIN), to organ-confined prostate cancer, to castration-resistant prostate cancer, and to metastatic disease. In contrast, PPAR $\gamma$ expression decreases from the organ confined to the metastatic stage and increases again to the castration-resistant stage.

It could not be confirmed that COX-2 and PPAR $\gamma$ are inversely expressed in the human breast cancers, as breast cancer histologies are quite heterogeneous and differentially express COX-2 and PPAR $\gamma$ [32]. Activation of PPAR $\gamma$ may cause COX-2 inhibition or the down-regulation of COX-2 expression [33], whereas the inhibition of COX-2 resulted in PPAR $\gamma$ activation [34] or up-regulation of PPAR $\gamma$ expression [35].

Additional series of TMAs consisted of $88 \mathrm{MM}$ with follow-up data, $101 \mathrm{MM}$ metastases, and 161 benign nevi. A further TMA $(n=194)$ consisted of MM metastases from 36 patients with metastatic stage IV melanoma who had participated in a randomized phase II trial using a stroma-directed biomodulatory approach combining COX-2/ PPAR $\gamma$-targeting with metronomic low-dose chemotherapy [18].

COX-2 and PPAR $\gamma$ immunoreactivity were paralleled and significantly increased from benign nevi (51\%/0\%) to primary MM (86\%/22\%) and MM metastases ( $91 \% / 33 \% ; p<0.001$, respectively). In the case of primary MM, positive COX-2 staining was associated with advanced Clark levels $(p=0.004)$ and shorter recurrence free survival $(p=0.03)$. However, PPAR $\gamma$ expression in primary MM was not associated with any of the clinic-pathologic characteristics or tumor progression and overall survival [18].

On the other hand, patients $(n=36)$ with PPAR $\gamma$ positive MM metastases who had been treated either with pro-anakoinotic metronomic low-dose chemotherapy (trofosfamide) alone or combined with COX-2/ PPAR $\gamma$-targeting drugs, i.e., rofecoxib and pioglitazone, showed a significant advantage concerning progression-free survival $(p=0.044)$, but not overall survival $(p=0.179)$. Expression of COX-2 (score 2+-3+) in the metastases, however, was not associated with overall and progression-free survival, respectively [36].

We conclude that the expression of COX-2 and PPAR $\gamma$ is a frequent finding in the progression of MM. Regarding primary MM, the expression of COX-2 indicates an increased risk of tumor recurrence, i.e., melanoma progression.

In metastatic MM, the expression of PPAR $\gamma$ may serve as positive predictive marker of potential responsiveness to anakoinosis-inducing stroma-targeted therapy [36].

\section{PPAR $\gamma$ Expression in Tumor Stroma}

Apart from specifically stroma cells targeting drugs, some well-established pro-anakoinotic drugs, among them NR agonists, have revealed antitumor activity by unfolding pleiotropic biological effects. In this context thiazolidinedione derivatives such as pioglitazone are of special interest as they exert 
both a direct anti-tumor and a broad spectrum of stromal activities, including modulation of immune response, angiogenesis, and inflammation [37].

Stroma cell-specific NR signatures have to be suggested to collectively influencing tumor proliferation and metastasis [38]. Compartment specific NR expression and their context-dependent interaction with coregulators of NRs facilitate a complex dysregulated communicative network of transcription factors supporting multifold biologic hallmarks and tumor growth. On this presumably stage- and tumor-dependent background of NR expression, the profiling of NRs in stroma cells is urgently warranted for providing further rationales for combined transcriptional modulation in a therapeutic setting.

\section{Induction of Anakoinosis with Master Modulators}

Expression patterns of PPAR $\gamma$ in histologic different tumor tissues, both in tumor cells and adjacent stroma cells indicate histology and even tumor stage specific characteristic patterns, even, as shown, with predictive impact. Tumor-specific patterns of PPAR $\gamma$ expression support that PPAR $\gamma$ is strongly involved in maintaining homeostatic processes by adapting lipid and carbohydrate metabolism to respective tumor specific conditions, and by controlling tumor suppressor gene expression for keeping homeostatic pathways under tumor growth-promoting conditions, such as Wnt, Hippo-YAP pathway, etc. [27,39-41].

Consecutively, many experimental data indicate that PPAR $\gamma$ agonists may modulate multifold biologic hallmarks in cancer: Cell cycle, differentiation, proliferation, apoptosis, and oxidative stress, innate immunity, angiogenesis, and inflammation [42-44].

However, in most trials, thiazolidinediones (TZD) do not show any clinically relevant anti-cancer activity when used in mono-therapy (Table 2). Therefore, clinical inefficacy contrasts ambiguous pre-clinical data mostly favoring anti-tumor activity, but also tumor promotion. Thus, most review papers come to no consistent conclusion about the clinical use of PPAR $\gamma$ agonists for cancer treatment.

In contrast, if thiazolidinediones are combined with additional regulatory active drugs, so-called 'master modulators' of tumors, i.e., transcriptional modulators, metronomic low-dose chemotherapy, epigenetically modifying agents, protein binding pro-anakoinotic drugs, such as COX-2 inhibitors, IMiDs etc., clinical results indicate the relevant communicative reprogramming of tumor tissues, i.e., anakoinosis, meaning 'communication' in ancient Greek (Table 1). 
Table 2. Glitazones including treatment schedules in metastatic cancer or hematologic neoplasia.

\begin{tabular}{|c|c|c|c|c|c|c|}
\hline \multirow[b]{2}{*}{ Neoplasia } & \multicolumn{5}{|c|}{ Glitazones in Refractory Tumors or Hematologic Neoplasia } & \multirow[b]{2}{*}{ Reference } \\
\hline & $\begin{array}{l}\text { No } \\
\text { pts }\end{array}$ & $\begin{array}{l}\text { Chemotherapy } \\
\left({ }^{*}=\text { Metronomic }\right)\end{array}$ & $\begin{array}{c}\text { Transcriptional } \\
\text { Modulators }\end{array}$ & $\begin{array}{c}\text { Small } \\
\text { Molecule }\end{array}$ & Best Response & \\
\hline \multicolumn{7}{|l|}{ Sarcomas } \\
\hline $\begin{array}{l}\text { Liposarcomas, intermediate to } \\
\text { high-grade (case reports) }\end{array}$ & - & - & Troglitazone & - & $\begin{array}{l}\text { Histological and biochemical } \\
\text { differentiation }\end{array}$ & [45] \\
\hline Liposarcoma & 3 & Trofosfamide * & Troglitazone & - & $\begin{array}{l}\text { Lineage-appropriate differentiation } \\
\text { can be induced pharmacologically in } \\
\text { a human solid tumor. }\end{array}$ & [46] \\
\hline $\begin{array}{l}\text { Liposarcoma } \\
\text { (Phase II study) }\end{array}$ & 12 & - & Rosiglitazone & - & $\begin{array}{l}\text { Rosiglitazone is not effective as an } \\
\text { antitumoral drug in the treatment of } \\
\text { liposarcomas }\end{array}$ & [47] \\
\hline Kaposi sarcoma, refractory & 1 & Trofosfamide * & Pioglitazone & COX-2 inhibitor & Partial remission & [48] \\
\hline (Hem-)angiosarcomas & 12 & Trofosfamide * & Pioglitazone & COX-2 inhibitor & Continuos complete remission & [49] \\
\hline $\begin{array}{c}\text { Breast cancer } \\
\text { Refractory breast cancer (Phase II study) }\end{array}$ & 22 & - & Troglitazone & - & No significant effect & [50] \\
\hline \multicolumn{7}{|l|}{ Melanoma } \\
\hline $\begin{array}{l}\text { Melanoma III (versus DTIC), phase II } \\
\text { ClinicalTrials.gov:NCT01614301 }\end{array}$ & 6 & Trofosfamide * & Pioglitazone & $\begin{array}{l}\text { Temsirolimus } \\
\text { COX-2 inhibitor }\end{array}$ & $\begin{array}{l}\text { Partial remission, } \\
\text { Resolution of cachexia }\end{array}$ & [51] \\
\hline \multicolumn{7}{|l|}{ Melanoma (randomized) } \\
\hline Melanoma II Arm M & 35 & Trofosfamide * & Pioglitazone & - & Stable disease & [52] \\
\hline Arm A/M & 32 & Trofosfamide * & Pioglitazone & COX-2 inhibitor & Partial remission & \\
\hline \multicolumn{7}{|l|}{ Hepatocellular carcinoma } \\
\hline Hepatocellular carcinoma & 38 & Capecitabine* & Pioglitazone & COX-2 inhibitor & Partial remission & [4] \\
\hline \multicolumn{7}{|l|}{ Cholangiocellular carcinoma } \\
\hline Cholangiocellular carcinoma & 21 & Trofosfamide * & Pioglitazone & COX-2 inhibitor & Partial remission & [18] \\
\hline Colorectal cancer & & & & & & \\
\hline $\begin{array}{l}\text { Chemotherapy-resistant metastatic } \\
\text { colorectal cancer (phase II study) }\end{array}$ & 25 & - & Troglitazone & - & $\begin{array}{l}\text { Not active for the treatment of } \\
\text { metastatic colorectal cancer }\end{array}$ & [53] \\
\hline \multicolumn{7}{|l|}{$\begin{array}{l}\text { Renal clear cell carcinoma } \\
\text { (historic comparison) }\end{array}$} \\
\hline Renal clear cell carcinoma, relapsed & 18 & Capecitabine* & Pioglitazone & COX-2 inhibitor & Partial remission & [54] \\
\hline Renal clear cell carinoma, relapsed & 33 & Capecitabine * & $\begin{array}{l}\text { Pioglitazone } \\
\text { Interferon-alpha }\end{array}$ & COX-2 inhibitor & Continuous complete remission & {$[5]$} \\
\hline \multicolumn{7}{|l|}{ Prostate cancer } \\
\hline Prostate cancer & 41 & - & Troglitazone & - & $\begin{array}{l}\text { Lengthened stabilisation of } \\
\text { prostate-specific antigen }\end{array}$ & [55] \\
\hline Castration-resistant prostate cancer & 61 & Treosulfan * & $\begin{array}{c}\text { Pioglitazone, } \\
\text { Dexamethasone }\end{array}$ & $\begin{array}{l}\text { COX-2 inhibitor } \\
\text { Imatinib }\end{array}$ & $\begin{array}{l}\text { Long-term tumor control at minimal } \\
\text { disease }\end{array}$ & [56] \\
\hline Castration-resistant prostate cancer & 36 & Capecitabine * & $\begin{array}{l}\text { Pioglitazone, } \\
\text { Dexamethasone }\end{array}$ & COX-2 inhibitor & Long-term tumor control & {$[57,58]$} \\
\hline
\end{tabular}


Table 2. Cont.

\begin{tabular}{|c|c|c|c|c|c|c|}
\hline \multirow[b]{2}{*}{ Neoplasia } & \multicolumn{6}{|c|}{ Glitazones in Refractory Tumors or Hematologic Neoplasia } \\
\hline & $\begin{array}{l}\text { No } \\
\text { pts }\end{array}$ & $\begin{array}{c}\text { Chemotherapy } \\
\left({ }^{*}=\text { Metronomic }\right)\end{array}$ & $\begin{array}{c}\text { Transcriptional } \\
\text { Modulators }\end{array}$ & $\begin{array}{c}\text { Small } \\
\text { Molecule }\end{array}$ & Best Response & Reference \\
\hline \multicolumn{7}{|l|}{ Prostate carcinoma (randomized) } \\
\hline $\begin{array}{l}\text { Rising serum prostate-specific antigen } \\
\text { level after radical prostatectomy and/or } \\
\text { radiation therapy }\end{array}$ & 106 & - & $\begin{array}{c}\text { Rosiglitazone Versus } \\
\text { Placebo }\end{array}$ & & $\begin{array}{l}\text { Rosiglitazone did not increase PSA } \\
\text { doubling time or prolong the time to } \\
\text { disease progression }\end{array}$ & [59] \\
\hline $\begin{array}{c}\text { Gastric cancer (randomized) } \\
\text { Gastric cancer Arm A/M } \\
\text { Arm M }\end{array}$ & $\begin{array}{l}21 \\
21\end{array}$ & $\begin{array}{l}\text { Capecitabine * } \\
\text { Capecitabine * }\end{array}$ & Pioglitazone & COX-2 inhibitor & $\begin{array}{c}\text { Partial remission } \\
\text { Pioglitazone no impact }\end{array}$ & {$[60]$} \\
\hline $\begin{array}{c}\text { Glioblastoma } \\
\text { Glioblastoma, refractory }\end{array}$ & 14 & Capecitabine * & Pioglitazone & COX-2 inhibitor & Disease stabilization & [61] \\
\hline $\begin{array}{c}\text { Multiple myeloma } \\
\text { Multiple myeloma, third-line } \\
\text { Clinicaltrials.gov, NCT001010243 }\end{array}$ & 6 & Treosulfan * & $\begin{array}{c}\text { Pioglitazone, } \\
\text { Dexamethasone }\end{array}$ & Lenalidomide & Complete remission & [62] \\
\hline $\begin{array}{l}\text { Langerhans cell histiocytosis } \\
\text { Langerhans cell histiocytosis, } \\
\text { refractory }\end{array}$ & $2+7$ & Trofosfamide * & $\begin{array}{c}\text { Pioglitazone } \\
\text { Dexamethasone }\end{array}$ & COX-2 inhibitor & Continuous complete remission & {$[13,63,64]$} \\
\hline $\begin{array}{c}\text { Hodgkin's lymphoma } \\
\text { Hodgkin lymphoma, refractory }\end{array}$ & 3 & Treosulfan * & $\begin{array}{c}\text { Pioglitazone, } \\
\text { Dexamethasone }\end{array}$ & $\begin{array}{l}\text { COX-2 inhibitor } \\
\text { Everolimus }\end{array}$ & $\begin{array}{c}\text { Continuous } \\
\text { complete remission }\end{array}$ & [65] \\
\hline $\begin{array}{c}\text { Chronic myelocytic leukemia } \\
\text { Chronic myelocytic leukemia without } \\
\text { moleclar CR } \\
\text { Acute myelocytic leukemia }\end{array}$ & 24 & - & Pioglitazone & Imatinib & $\begin{array}{l}\text { Molecular complete remission } \\
\qquad(54 \%)\end{array}$ & [66] \\
\hline $\begin{array}{l}\text { Acute myelocytic leukemia } \\
\text { Refractory (on-going trial) }\end{array}$ & $5+7$ & Azacitidine & $\begin{array}{l}\text { Pioglitazone All-trans } \\
\text { retinoic acid }\end{array}$ & & $\begin{array}{l}\text { Molecular complete remission } \\
\text { Myelodysplastic synrome with } \\
\text { phagocytically active blasts }\end{array}$ & {$[67,68]$} \\
\hline
\end{tabular}


5. Keys for Uncovering the Therapeutic Potential of PPAR $\gamma$ Agonists: Selecting the Appropriate, Histology-Independent Combination of Master Modulators

Clinical data reveals that most regulatory active drugs, i.e., master modulators of tumor tissues, exert only a modest or no monoactivity in cancer treatment (Table 2). Also, metronomic low-dose chemotherapy has just modest activity in randomized comparisons [69-75].

However, combining master modulators in 17 different histologic tumor entities leads to impressive, and, interestingly, highly diversified tumor responses up to continuous complete remission (Table 2). Moreover, single combinatory schedules of master modulators, including pioglitazone, are cross-responsive among quite different tumor histologies [12,51]. Cross-responsiveness now clearly indicates that different tumor histologies share identical patterns of hallmarks of cancer and constitute similar physical organizations of hallmarks, so called rationalizations of hallmarks, despite underlying (molecular-) genetic tumor heterogeneity (Table 1).

Thus, the clinically used top-down approaches reveal that tumor phenotypes are not dominantly minted and are associated with multifold recessively developing tumor features, which may be accessible for the concerted activity of regulatory active drugs. The specific therapeutic and clinically relevant access to tumor systems prompted us to choose for the procedure the term 'anakoinosis', communicative reprogramming [12]. The term anakoinosis reflects how regulatory active drugs may concertedly induce major tumor response, obviously by altering validity, i.e., availability on demand at distinct time points, and denotation, i.e., current functional impact at a distinct systems stage of tumor-promoting pathways (Table 1, Figure 1).

\begin{tabular}{|c|c|c|}
\hline \multicolumn{3}{|c|}{$\begin{array}{l}\text { Clinical observations in } \mathbf{1 8 8} \text { patients with seven different tumor types treated with } \\
\text { pro-anakoinotic therapy approaches } \\
\text { Pioglitazone: Multilevel activity profiles } \\
\text { [Walter at al., 2017; Hart et al, 2015; Hart et al, 2016] }\end{array}$} \\
\hline Mechanisms of action & \multicolumn{2}{|c|}{$\begin{array}{l}\text { De-repression of tumor suppressor genes, regulation of homeostatic pathways, } \\
\text { modulation of tumor cell energy and lipid metabolism }\end{array}$} \\
\hline $\begin{array}{l}\text { Modulation of biologic } \\
\text { hallmarks }\end{array}$ & \multicolumn{2}{|c|}{$\begin{array}{l}\text { Cell cycle, differentiation, proliferation, apoptosis, and oxidative stress, innate } \\
\text { immunity, angiogenesis, inflammation }\end{array}$} \\
\hline Clinical outcome & \multicolumn{2}{|c|}{ Diversification of palliative care and continuous complete remission } \\
\hline \multicolumn{2}{|c|}{$\begin{array}{l}\text { Coping with metastatic argan/organism involvement } \\
\text { - Restitutio ad integrum or defective healing } \\
\text { - Inhibiting metastatic process } \\
\text { - Improvement of quality of life }\end{array}$} & $\begin{array}{l}\text { Activating specific evolutionary processes } \\
\text { - Differentiation and regain of functions } \\
\text { - Induction of biologic memory } \\
\text { - Restauration of anti-hormonal response } \\
\text { - Reduction of metastatic potential } \\
\text { - Coping with genetic tumor heterogeneity, undruggable' targets, } \\
\text { and resistance }\end{array}$ \\
\hline \multicolumn{2}{|c|}{$\begin{array}{l}\text { Coping with modularity of systems participators } \\
\text { - Very delayed or rapid response } \\
\text { - Active' chronification of a tumor disease at minimal } \\
\text { residual disease } \\
\text { - Regain of apoptosis/differentiation competence } \\
\text { - Continuous complete remission }\end{array}$} & $\begin{array}{l}\text { Reconfiguring and establishing biologic, hallmorks" } \\
\text { - Inflammation control } \\
\text { - Resolution of immunotolerance } \\
\text { - Differential establishment of rationalizations for biologic hallmarks } \\
\text { - Convergent evolution: Different histologies share response to } \\
\text { identical master modulators }\end{array}$ \\
\hline
\end{tabular}

Figure 1. Pioglitazone in tumor therapy regulates the communicative interface of transcriptional modulation, lipid and carbohydrate metabolism, particularly in combination with additional master modulators. Thus, tumor-promoting pathways can be functionally attenuated without direct blocking tumor-promoting pathways or by shutting off tumor-associated cellular compartments. Clinical equivalents are diversification of palliative care, even continuous complete remission. 
The fact that communication rules may change validity and denotation of systems objects may be generally attributed to communication.

The successful concerted administration of pro-anakoinotic drug combinations, including PPAR $\gamma$ agonists in the clinical setting, may now explain multiple, from the clinical point of view cumulatively vague, as always context-dependent and often opposing results on the function of PPAR $\gamma$ agonists $[1,6,24,76-84]$. The missing conception for integrating pre-clinical results in clinical practice underlines missing communication-based therapeutic paradigms provided by an evolution-adjusted tumor pathophysiology and implies an unjustified hesitant introduction of master modulators, including PPAR $\alpha / \gamma$ agonists, like pioglitazone in tumor therapy (Table 1).

Pre-clinically synergistic activities of PPAR $\gamma$ have been reviewed, particularly combinations with chemotherapy, besides RXR ligands and statins [82].

\subsection{Poor Monoactivity of PPAR $\gamma$ Agonists Across Different Tumor Histologies}

Monoactivity of glitazones in cancer patients is very modest, whereas strong activity is well established in single tumor histologies for dexamethasone, all-trans retinoic acid, and bexarotene $[11,85]$.

Metabolically active drugs, such as metformin or PPAR $\gamma / \alpha$ agonists, are considered as chemopreventive agents [86,87]. Metformin may prolong survival in cancer patients following surgery, but only in distinct histologic tumor types, as retrospective studies are indicating [88]. Nevertheless, very recent data shows a mechanistic link between glucose metabolism and cancer being mediated by TET2-function [89].

Agonists of 'adopted' orphan receptors commonly have poor monoactivity in interventional cancer trials [59,90], in contrast to hormones and cytokines [91,92]. Particularly, dexamethasone plays a decisive role in the induction treatment for acute lymphocytic leukemia or multiple myeloma [90].

\subsection{PPAR $\gamma$ Agonists in Pro-Anakoinotic Combination Therapy with Master Modulators}

Stromal cells or normal epithelial cells are not equipped for directly sensing tumor promoting genetic or molecular-genetic aberrations in neighboring malignant transformed cells. Adjacent non-tumor cells, however, sense dysregulations in homeostatic pathways. Thus, it is not surprising that hair follicle epithelia may spontaneously eliminate malignant transformed counterparts, irrespective of the underlying oncogenic events by sensoring dysregulated homeostasis [93].

Therefore, our commonly used therapeutic procedure, based on 'sensing' and consecutively blocking oncogenic pathways, is completely different from the pathophysiological based in vivo recognition of equivalences of malignancy by non-tumor cells, i.e., dysregulated homeostatic processes. All tumor-associated (molecular-) genetic aberrations are profoundly involved in dysregulations of homeostatic pathways [14]. Thus, tumors can be considered as a big dysregulated network of transcription factors. Just the communicatively evolving transcriptional system irregularities may be recognized as therapeutic target for master modulators. Master modulators are equipped with the capacity for 'normalizing' homeostatic networks on quite different topographic levels: the tumor's different cell compartments, the tumor and the tumor-harboring organ, and finally, the tumor and the whole organism (Table 1) [12].

Dysregulated homeostatic pathways represent, even if complex for pre-clinical evaluation, a pivotal therapeutic tool for 'normalizing' dysregulated homeostatic processes via master modulators, including agonists of nuclear transcription factors. NR antagonists are well integrated in clinical use and are here excluded from consideration. The review, particularly, concentrates on pioglitazone, a dual receptor agonist for PPAR $\alpha / \gamma$.

As shown to some extent, tumor-associated transcriptional dysregulation provides access for specific pro-anakoinotic effects via master modulators, including NR agonists. Moreover, histologically different tumor types share distinct communication-derived dysregulations, independent of the oncogenic background and show cross-reactivity to distinct systems adapted combinations of master modulators [12]. 
Cancer-specific impressive transcriptional dysregulation in comparison to the homeostatically well-balanced repertoire of transcription factors in normal organ tissue might be responsible for the modest toxicity profile of therapies, including combinations of master modulators. Therapeutic effects of combinations of master modulators should be to some degree neglectable in homeostatically well balanced, normal tissues, as they do not lay themselves open to therapeutic attack with master modulators selected for special evolution-related operative conditions in tumor tissue (Table 1) [12].

The top-down approach only has established how agonists of nuclear transcription factors, or generally master modulators, might communicatively interact for diversifying palliative care or even for inducing continuous complete remission. Additionally, maximal tolerable doses can be yield up, as pro-anakoinotic acting, lower doses are sufficient for achieving a therapeutically relevant response (Figure 2).

\section{Pioglitazone: Operating communication processes in tumors}

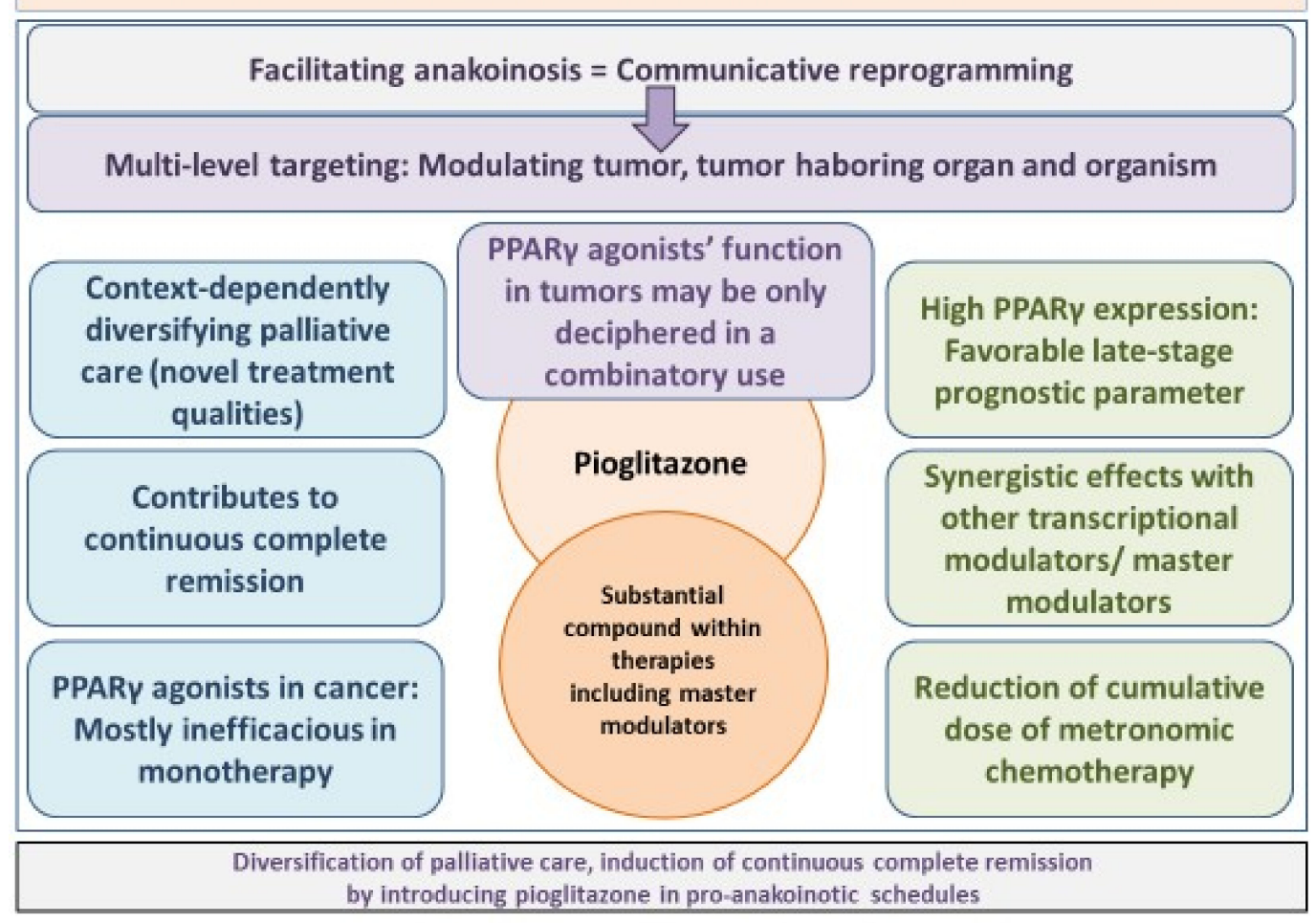

Figure 2. Pioglitazone, operating communication processes in tumors: Clinical relevance.

5.2.1. PPAR $\gamma$ Agonists Combined with Metronomic Low-Dose Chemotherapy/Demethylating Agents

Metronomic low-dose chemotherapy is still not established in routine therapy of neoplasia, as randomized comparisons often show no advantage for metronomically scheduled chemotherapy [69-75]. However, pre-clinical and clinical data give hints that the addition of classic targeted therapies or master modulators may improve outcome, even may diversify palliative care, and may contribute to continuous complete remission [94].

There are several reasons to include metronomic low-dose chemotherapy in the group of master modulators of tumor tissues. By adding pioglitazone and a COX-2 inhibitor, or an additional transcriptional regulator, such as a glucocorticoid, all-trans retinoic acid or interferon- $\alpha$, outcome in refractory metastatic tumor disease could be improved up to continuous complete remission (Table 2). Additionally, chemotherapy doses could be reduced up to a quarter or third of the respective cumulative dose, which would be administered as pulsed therapy every three to four weeks, without 
loss of efficacy. Therefore, currently the question remains unanswered, which is the lowest, still regulatory active dose of metronomic chemotherapy when combining several master modulators [12].

In metastatic melanoma, the addition of pioglitazone to metronomic low-dose chemotherapy and COX-2 inhibitor has important therapeutic impact on outcome, as indicated in the paragraph 'PPAR $\gamma$ agonist plus COX-2 inhibitor'.

An important link between pioglitazone and metronomic chemotherapy may be physically explained. Pioglitazone sensitizes metronomic low-dose chemotherapy response by up-regulation of both, the receptor for the angiogenesis inhibitor thrombospondin 1, CD 36, and the phosphatase and tensin homolog PTEN [95-98].

\subsubsection{PPAR $\gamma$ Agonists Plus Dexamethasone}

Interacting with transcription factors as well as other cell-signaling systems nuclear receptors are important regulators in innate and adaptive immunity. PPARs, LXRs, and the glucocorticoid receptor (GR) may act together and thereby integrate local and systemic responses to inflammation by p65/IRF3-independent mechanisms [99]. Cooperating with the GR PPARs und LXRs synergistically transrepress distinct subsets of toll-like receptor-responsive genes. Thus, the combinatorial control of homeostasis and immune responses by nuclear receptors may specify the response and suggest novel approaches for treatment of pro-inflammatory tumor diseases [99].

In a series of quite different tumor histologies, the cross-responsiveness to dual transcriptional modulation with pioglitazone and glucocorticoid could be nicely shown, when added to metronomic low-dose chemotherapy. The concept has been tested in multiple myeloma, Hodgkin disease, and Langerhans cell histiocytosis, all inflammation-triggered diseases. C-reactive protein control in peripheral blood was indicative for response [12,63].

Preclinical data show that thiazolidinediones induce growth arrest and apoptosis of Waldenström's macroglobulinemia cells, at concentrations that are relevant to those achieved in previous clinical uses of these drugs [100].

From pre-clinical data on prostate cancer, PPAR $\gamma$ agonists may be acting, in part, by inhibiting transactivation of androgen-responsive genes [101]: Peroxisome proliferator-activated receptor $\gamma$ agonists may down-regulate prostate-specific antigen expression in human prostate cancer [102].

Positive correlation between PPAR $\gamma$ and fatty acid synthase (FASN) protein in prostate cancer cell lines and synergism between TZDs and FASN blockers could be shown in prostate cancer cell viability reduction and apoptosis induction. [103].

Androgen receptor and Wnt/ $\beta$-catenin/Tcf are cross-regulated. RAR/RXR, GR, thyroid receptor (TR), vitamin D receptor (VDR), estrogen receptor (ER), and PPAR modulate canonical Wnt signaling in dynamic manner with striking cell line- and tissue-specific differences indicating selective therapeutic access and requiring deciphering for combined transcriptional modulation in a therapeutic setting [40]. This fact may give hints for the combinatorial use of receptor agonists and antagonists.

Dual transcriptional modulation with glucocorticoids and pioglitazone in combination with metronomic low-dose chemotherapy and COX-2 inhibitor improved in a historic comparison overall survival in high-risk patients with castration-resistant prostate cancer from 19 months to more than three years. The addition of imatinib had no impact in this trial [56].

Thus, rapidly progressive castration-resistant prostate cancer responded to the same therapy principle as refractory Hodgkin disease, multiple myeloma, and Langerhans cell histiocytosis, but the communication-technically provided dysregulated systems targets seem to be different. Castration-resistant prostate cancer is only in rare cases that are associated with pro-inflammatory systems reaction, and C-reactive response in serum was no indicator for response as in refractory Hodgkin disease, multiple myeloma, and Langerhans cell histiocytosis [54,63-65] 


\subsubsection{PPAR $\gamma$ Agonists Plus All-Trans Retinoic Acid}

The combination of azacitidine plus all-trans retinoic acid and pioglitazone may induce ex vivo granulocytic differentiation in more of $50 \%$ of blasts from acute myelocytic leukemia [67]. Moreover, these granulocytes regain phagocytic activity, when exposed to E. coli (unpublished data). Clinically, it is possible to induce continuous complete remission in acute myelocytic leukemia with the triple combination, while using only about $50 \%$ of the recommended dose of azacitidine $[67,104]$.

A randomized trial in refractory acute myeloid leukemia (AML) is on-going, comparing the approved dose of azacitidine in comparison to the dose per square meter plus all-trans retinoic acid and pioglitazone.

Synergistic activity of dual transcriptional modulation has been well established in pre-clinical studies, for example, for pioglitazone and all-trans retinoic acid in tumor cell lines of different histology [68,105-108], but also for glitazones in combination with chemotherapy [76]. Clinical trial designs translated these pre-clinical results comparatively hesitantly.

\subsubsection{PPAR $\gamma$ Agonists Plus Interferon- $\alpha$}

In renal clear cell carcinoma (RCC), IL-6 is a prognostic factor for survival [109]. Vice versa, in anakoinosis-inducing trials, including pioglitazone, C-reactive protein response to anakoinosis-inducing therapy is indicating tumor response [110].

Interferon- $\alpha$ is an approved drug in RCC and acts strongly anti-inflammatory by inducing circulating tumor necrosis factor receptor p55 and mediates a rapid and strong C-reactive protein (CRP) decrease by inhibiting TNF $\alpha$. RCC is a tumor, producing directly CRP, not only mediated via liver [111].

In a first trial, pioglitazone combined with metronomic chemotherapy and COX-2 inhibitor relatively poor response, mainly stable disease could be observed in $>$ third line situation. The addition of low-dose interferon- $\alpha$ opened the possibility to induce histologically proven remission in resistant metastatic RCC, which translated in continuous complete remission, now lasting $>10$ years in single patients [5].

Interestingly, interferon- $\alpha$ is active in renal cell carcinoma, both in combination with retinoids or pioglitazone $[5,112,113]$.

\subsubsection{PPAR $\gamma$ Agonists Plus COX-2 Inhibitor}

COX-2 inhibition is tightly regulating cellular levels of fatty acids and their derivatives, which are mainly derived from the lipoxygenase and cyclooxygenase pathways. Modulating COX-2 activity influences the local availability of PPAR ligands, therefore indirectly PPAR activity [114].

Inhibiting the canonical Wnt signaling pathway, nonsteroidal anti-inflammatory drugs as well as PPAR $\gamma$ agonists are candidate agents for chemoprevention. Celecoxib suppresses cancer stemness and the progression of hepatocellular carcinoma via activation of PPAR $\gamma$ and up-regulation of PTEN [115]. COX-2 and peroxisome proliferator-activated receptor delta are involved in important growth promoting signaling pathways in human hepatocellular carcinoma [116]. The non-steroidal anti-inflammatory drugs (NSAID)-dependent inhibiton of COX-2 and activation of PPAR $\gamma$ has been shown to suppress cancer stem cells in colon cancer [97]. Celecoxib, for instance, induces up-regulation of PTEN in N1-S1 cells. This process can be enhanced by rosiglitazone. Moreover, it has also been shown that celecoxib increases PPAR $\gamma$ expression and PTEN activity in wild-type and COX-2-deleted Huh7 cells [117]. Concerning the mechanism, within the PTEN promoter, two putative PPAR $\gamma$ binding sites have been identified [96].

Anti-tumor-effects of a cyclooxygenase- 2 inhibitor and a peroxisome proliferator-activated receptor $\gamma$ agonist have been also demonstrated in an in vivo mouse model of spontaneous breast cancer $[43,118]$. 
In a series of clinical trials, we used pioglitazone combined with rofecoxib or etoricoxib. From one randomized trial in metastatic melanoma, at least the impact of pioglitazone in addition to COX-2 inhibitor and metronomic low-dose chemotherapy may be delineated. High PPAR $\gamma$ expression in melanoma cells is a favorable prognostic factor for progression-free survival. PPAR $\gamma$ is a late stage predictive marker in metastatic melanoma, and PFS is significantly improved by adding pioglitazone to a pro-anakoinotic schedule, including metronomic low-dose chemotherapy and COX-2 inhibitor (Table 2).

It is not possible to directly estimate the clinical impact of the COX-2 inhibitor from single arm pioglitazone and COX-2 inhibitor, including trials in addition to metronomic low-dose chemotherapy.

\subsubsection{PPAR $\gamma$ Agonists and IMiDs}

In an animal model, pomalidomide enhances the expression of PPAR $\gamma$ and CCAAT/enhancer binding protein $\alpha(\mathrm{C} / \mathrm{EBP} \alpha)$, as well as the activity of lipoprotein lipase (LPL) and fatty acid synthetase (FAS). The pro-inflammatory activity of TNF $\alpha$ has the opposite effect on the biochemical indexes and genes that are related to lipid deposition in the liver [119].

Additional experimental data on tumor growth inhibition implicate thalidomide as being involved in the PPAR $\gamma$ pathway. Thalidomide and pomalidomide increase PPAR $\gamma$ protein dose-dependently, also activity of peroxisome proliferator response element [120].

In a clinical trial on multiple myeloma, we successfully used pioglitazone and lenalidomide plus low-dose metronomic chemotherapy and glucocorticoid for rescuing patients following failure of lenalidomide containing regimens in > third line therapy. All of these modulating activities justify for including IMiDs to master modulators of tumor tissue [63].

\subsection{PPAR $\gamma$ Agonists in Pro-Anakoinotic Combination Therapy Combined with Targeted Therapy}

\subsubsection{Pioglitazone and Imatinib}

Pioglitazone with imatinib in CML may reduce minimal residual disease. PPAR $\gamma$ agonists target chronic myeloid leukemia (CML) quiescent stem cells in vitro by decreasing transcription of STAT5. A fact that was also shown in multiple myeloma for STAT3. A phase III trial is on-going in France when comparing imatinib versus imatinib plus pioglitazone, as front-line therapy for CML [121].

The addition of imatinib in prostate cancer had no impact on outcome, although there are strong pre-clinical results indicating an impact of imatinib on potentially clinical relevant PDGFR inhibition in prostate cancer [57].

\subsubsection{PPAR $\gamma$ and Mechanistic Target of Rapamycin (mTOR) Inhibitor}

An additive or synergistic activity of thiazolidinediones and mTOR inhibitors can be suggested from pre-clinical data. Activation of PPAR $\gamma$ by thiazolidinediones leads to inhibition of cell growth and proliferation via key pathways of the Insulin/IGF axis, such as PI3K/mTOR, mitogen-activated protein kinase (MAPK), and GSK3- $\beta /$ Wnt / $\beta$-catenin cascades. This signal pathways regulate cancer cell survival, cell reprogramming, and differentiation [84]. The inhibitory effect of rosiglitazone on non-small cell lung cancer (NSCLC) cell growth was enhanced by the mTOR inhibitor rapamycin. Rosiglitazone, via up-regulation of the PTEN/AMPK and down-regulation of the Akt/mTOR/p70S6K signal cascades, inhibits NSCLC cell proliferation through PPAR $\gamma$-dependent and PPAR $\gamma$-independent signals [122].

In refractory Hodgkin disease and MM, an mTOR inhibitor was introduced in addition to pioglitazone, metronomic low-dose chemotherapy, and COX-2 inhibitor; in Hodgkin lymphoma, a glucocorticoid was used, additionally. Metastatic uveal melanomas responded with long-term disease stabilization, improvement of Eastern Cooperative Oncology Group (ECOG) status and resolution of cachexia. In fourth-line PET negative complete remissions were achieved in Hodgkin lymphomas. All patients received allogeneic blood stem cell transplantation in first complete remission $[51,66]$. 
Both neoplasia are poorly responding to mTOR inhibitors, only. Thus, also the use of classic targeted therapy, here, the mTOR inhibitor may be repurposed [123].

\section{Specific Methodological Aspects of Anakoinosis Inducing Therapies}

\subsection{Communication Tools}

The successful use of pro-anakoinotic therapy approaches gives hints that generally available evolutionary strategies of single cells and tissues may be therapeutically recalled and accessed, particularly in the diseased stage, characterized by transcriptional dysfunctions.

As clinically shown, operating communication tools, including master modulators, evolves therapeutic capacity for biologically 'neutralizing' tumor promoting systems features without blocking tumor-relevant pathways or without targeted elimination of cell compartments of the tumor. The suggestion of communication tools seems to oppose molecular-biologic thinking in networking pathways supposing structures, functions, and hubs with simplistically presumed invariant validity and denotation. However, those classic pathway paradigms disregard that each systems object, also that in a tumor, whatever it will represent physically, a structure, such as a molecule or cell, a function or hub, may be intrinsically or extrinsically, namely therapeutically, nudged by communication derived impulses for context-dependently changing its validity and denotation. Secondly, the identity of structures, functions, or hubs is always communicatively mediated, and necessarily includes and depends on the environmental conditions, functioning as boundary conditions, and integrates the scientific point of view, which is invariably subjected, even if it can be commonly objectively backtraced.

Communication within biologic systems works with the implicit understanding that (1) validity and denotation of systems objects, molecules, cells etc., is always context-dependent, (2) and may be therapeutically redeemed by master modulators via systems-immanent communication tools, which are determined by descriptively accessible communicative systems textures, including inter-systemic exchange processes. The difference between theory, the activity profile of systems participators under invariant 'standard conditions', and practice, the situative evolution-adjusted activity profile, may be bridged by operating communication tools inducing evolutionarily conserved and therapeutically retrievable evolutionary processes (Table 1, Figure 1) [124].

With the introduced paradigmatic changes, the circle can be closed, between multifaceted and contradictory pre-clinical results on the action of PPAR $\gamma$ agonists and unambiguous, reproducible clinical observations resulting from the combined use of master modulators, including NR agonists.

The clinical observations on therapies with master modulators also support experimental data that tumor development and progression is not only a matter of oncogenic events, but of the disease stage, an observation that is also supported by PPAR $\gamma$ expression and predictivity for progression-free survival in metastatic melanoma (Figure 2) [18].

NR agonists develop context and ligand dependent activity profiles. Therapeutic top-down approaches for treating refractory metastatic tumors and hematologic neoplasia indicate that the PPAR $\gamma$ agonists' clinical function may be only deciphered in a combinatory use. Only by introducing several master modulators in therapeutic schedules, including, for example, PPAR $\gamma$ agonists, master modulators develop the capacity for mutually specifying and enhancing response, now up to a clinically relevant level, which can be hardly achieved with mono-therapy, as shown by the missing monoactivity of PPAR $\gamma$ agonists in cancer treatment [12].

Clinical read-outs following combined administration of master modulators are also multifaceted, but reproducible, and they are resulting in diversified, clinically meaningful, palliative care, or response may even disembogue in continuous complete remission. Situative and stage-dependently varying communication features on the respective topographic levels, tumor tissue, tumor-harboring organ, and organism represent the therapeutic counterpart to the diversified context-dependent pre-clinical observations (Figure 1). In case of cachexia, cachexia may be resolved in metastatic melanoma with PPAR $\gamma$ agonist, including schedules with master modulators [51,125]. 
Importantly, the combined activity profile of PPAR $\gamma$ agonists plus further master modulators is highly specific. However, tumors may either share the communicative systems contexts and therefore, also the therapeutic accessibility towards distinct combinations of master modulators, or may be in the worst case unresponsive, due to the presence of alternative communicative systems contexts, or alternative constitutions of identical hallmarks of cancer.

At this step, individualization of pro-anakoinotic therapy could take place by describing the evolution-adjusted tumor pathophysiology, for example, via serum proteomics and metabolomics $[125,126]$.

\subsection{What Is the Appropriate Model System: From Histology to 'Evolution-Adjusted' Tumor Pathophysiology?}

The key for uncovering the therapeutic potential of PPAR $\gamma$ agonists is selecting the appropriate combination(s) of master modulators for inducing anakoinosis: Now, anakoinosis is trend setting by establishing a novel therapeutic pillar while overcoming classic obstacles of targeted therapies, such as therapy resistance and (molecular-)genetic tumor heterogeneity.

The clue is that different histologic tumor types share response to distinct combinations of master modulators. That means histologic systematics, in any case reaching its operational limitations in clinics, even by including molecular-pathology and molecular genetics, may be newly unlocked and re-systematized. For this purpose, the systematic specification of tumor-specific communication networks may be adducted, based on the ubiquitously available communication tools, and the evaluation of diversified rationalizations, i.e., physical constitutions of biologic hallmarks, including the hallmarks of cancer. Diversified rationalizations may constitute identical normative notions, for example, rapidly displacing growth of acute leukemias in bone marrow (Table 1). Thus, profound systematics of tumor-specific communication routes, not to be mixed up with the context-independently discussed tumor-promoting pathways, and knowledge about the situative physical constitution of rationalizations results in an 'evolution-adjusted' tumor pathophysiology, which may be prerequisite for the targeted selection of combinations with master modulators (Table 1). By operating anakoinosis in tumors, therapy may cope with the situative relativity of biologic systems, i.e., situative validity and denotation of systems objects in biologic systems. Master modulators may be successfully therapeutically applied for exploiting the possibilities of palliative care and for inducing continuous complete remission.

All communication guiding, validity, and denotation modulating structural, functional tools, including tuning of hubs, are principally therapeutically accessible with pro-anakoinotic drug cocktails, as shown for multiple histologic quite different tumor entities.

\subsection{What Is the Appropriate Dosage of Pro-Anakoinotic Therapy?}

Single dosages of master modulators, so the postulate, must sufficiently equip the tumor system with reprogramming capacity for attenuating tumor growth. The appropriate regulatory active dosage cannot be pharmacokinetically defined, yet. As clinically indicated, the combination of PPAR $\gamma$ agonists with metronomic chemotherapy facilitates dose-reduction of the cumulative chemotherapy dosage to a quarter or third of the pulsed dose given every three to four weeks without the loss of clinical efficacy.

The two different dose levels of pioglitazone 60 or $45 \mathrm{mg}$ daily seem not to have any impact on response. In addition, patients with both, reduced doses of metronomic chemotherapy, and with dose-reduction of pioglitazone achieved significant clinical response [12].

Within the combined pro-anakoinotic therapy schedules, typical, but modest side effects, can be attributed to the administration of pioglitazone [57,58]. Peripheral edema Grade I to II occurred in 52.4 to $58.5 \%$, including few Grade III toxicities in hepatocellular carcinoma due to pre-existing liver disease. Renal failure Grade I to II was observed in $13.2 \%$ of patients with hepatocellular carcinoma. Adverse events leading to dose adjustment or temporary interruption of therapy in the prostate cancer trial occurred in $13.8 \%$, permanent discontinuation in $1.2 \%$. In hepatocellular carcinoma, 
dose adjustments of pioglitazone (starting dose $60 \mathrm{mg}$ daily) were performed in $33 \%$ of patients, no permanent discontinuation.

\subsection{Pro-Anakoinotic Therapy Schedules: Indications and Diagnostics}

Up-to-now, anakoinosis inducing therapies, including pioglitazone, have been administered in metastatic and refractory cancer and hematologic malignancies. From the results of these trials (Table 2) a proof of principle can be delineated, namely activity of anakoinosis inducing therapies in poor-risk patient populations. First steps in the direction of combining classic targeted therapy with anakoinosis-inducing schedules were successful (Table 2). When considering tumor response as a timely multi-step biologic approach, during those reprogramming and classic targeted steps are repetitively and/or simultaneously necessary for inducing long-term tumor response, differential valuable clinical endpoints may be biologically accessible, such as induction of biologic memory, 'active' long-term chronification of tumor disease, or, in the best case, continuous complete remission. Anakoinosis inducing therapies could be perspectival integrated in ideal manner in classic targeted approaches. Classic targeted therapies may be even repurposed with many possible implications for additional clinical approvals [123].

Monitoring of such anakoinosis-inducing therapies must be completely reorganized in comparison to targeted therapies, where the availability of the target on the tumor or stroma cell is used as indicator for possible tumor response. Now, multiple parameter analysis derived from proteome and metabolome analytics from serum or plasma might be helpful, before and during therapy.

\section{Conclusions}

A long way of failures accompanied the introduction of PPAR $\gamma$ agonists in tumor therapy. In contrast to NRs that are activated by hormones and the prompt incipient activity of hormones, adopted NRs have an intrinsic tissue- and stage-dependent pro-anakoinotic activity profile, which is pointed in tumor tissues with their severe dysregulation of transcription factors. However, PPAR $\gamma$ agonists are clinically irrelevant, as far as, for example, PPAR $\gamma$ agonists are used in mono-therapy. With respect to pioglitazone, the tumor systems related activity profile may be exclusively focused and up graded to a clinically meaningful range by introducing additional NR agonists, as shown for glucocorticoids, all-trans retinoic acid, or the transcriptional modulator interferon- $\alpha$, or more generally, by adding master modulators. Under conditions of concerted activity of master modulators, it should be generally possible to elaborate and adopt combinations of master modulators inducing response in metastatic, refractory neoplasia, irrespective of the histologic origin.

Thus, with induction of anakoinosis, a novel therapy pillar may be introduced providing several advantages compared to classic targeted therapies:

Anakoinotic processes may cope with fundamental obstacles of classic targeted therapies, with tumor heterogeneity and poor risk parameters, with context-dependent validity and denotation of tumor-promoting aberrations and targets, with drug resistance or undruggable targets by targeting dynamic evolutionary processes, for example, multifaceted biologic steps that are necessary for establishing 'active' long-term tumor control or continuous complete remission [12]. Pro-anakoinotic therapies may inhibit further metastatic progression in case of metastatic disease (Table 1, Figure 1) [127].

Auspicious 'personalized' tumor therapy is now supplemented by a novel treatment methodology, which is at its beginnings but multifaceted adaptable to tumor systems stages. Importantly, metastatic tumors of quite different histologic origin may share communication features and may be reprogrammed with identical combinations of master modulators operating communication tools. Thus, in future, an evolution-adjusted tumor pathophysiology could be the driving force for specifying combinations of NR agonists and antagonists. Studies on proteomics and metabolomics in serum and plasma will provide new information on on-going systems changes induced by pro-anakoinotic therapy approaches. 
A randomized trial introducing in the experimental arm metronomic low-dose chemotherapy, a selective inhibitor of the enzyme steroid-17 $\alpha$-hydroxylase (CYP17A1), which catalysis steps in the testosterone and estrogen biosynthesis, and dual transcriptional modulation with glucocorticoid and pioglitazone is ongoing in castration-resistant prostate cancer. In a second on-going trial, pioglitazone and all-trans retinoic acid are combined with azacitidine in the experimental arm for treating refractory acute myelocytic leukemia.

Author Contributions: D.H. and A.R. wrote the manuscript. M.R., F.L., M.V., T.P., W.H., L.G., and C.G. gave critical comments, read and approved the final version of the manuscript.

Funding: This research received no external funding.

Acknowledgments: The authors thank the patients for participating in the trials and the investigators for their contributions.

Conflicts of Interest: The authors declare no conflict of interest.

\section{References}

1. Gou, Q.; Gong, X.; Jin, J.; Shi, J.; Hou, Y. Peroxisome proliferator-activated receptors (PPARs) are potential drug targets for cancer therapy. Oncotarget 2017, 8, 60704-60709. [CrossRef] [PubMed]

2. Dormandy, J.A.; Charbonnel, B.; Eckland, D.J.A.; Erdmann, E.; Massi-Benedetti, M.; Moules, I.K.; Skene, A.M.; Tan, M.H.; Lefèbvre, P.J.; Murray, G.D.; et al. Secondary prevention of macrovascular events in patients with type 2 diabetes in the PROactive Study (PROspective pioglitAzone Clinical Trial In macroVascular Events): A randomised controlled trial. Lancet 2005, 366, 1279-1289. [CrossRef]

3. Nissen, S.E.; Wolski, K. Effect of rosiglitazone on the risk of myocardial infarction and death from cardiovascular causes. N. Engl. J. Med. 2007, 356, 2457-2471. [CrossRef] [PubMed]

4. Walter, I.; Schulz, U.; Vogelhuber, M.; Wiedmann, K.; Endlicher, E.; Klebl, F.; Andreesen, R.; Herr, W.; Ghibelli, L.; Hackl, C.; et al. Communicative reprogramming non-curative hepatocellular carcinoma with low-dose metronomic chemotherapy, COX-2 inhibitor and PPAR- $\gamma$ agonist: A phase II trial. Med. Oncol. 2017, 34, 192. [CrossRef] [PubMed]

5. Walter, B.; Schrettenbrunner, I.; Vogelhuber, M.; Grassinger, J.; Bross, K.; Wilke, J.; Suedhoff, T.; Berand, A.; Wieland, W.F; Rogenhofer, S.; et al. Pioglitazone, etoricoxib, interferon- $\alpha$, and metronomic capecitabine for metastatic renal cell carcinoma: Final results of a prospective phase II trial. Med. Oncol. 2012, 29, 799-805. [CrossRef] [PubMed]

6. Dhiman, V.K.; Bolt, M.J.; White, K.P. Nuclear receptors in cancer-Uncovering new and evolving roles through genomic analysis. Nat. Rev. Genet. 2018, 19, 160-174. [CrossRef] [PubMed]

7. Capper, C.P.; Rae, J.M.; Auchus, R.J. The metabolism, analysis, and targeting of steroid hormones in breast and prostate cancer. Horm. Cancer 2016, 7, 149-164. [CrossRef] [PubMed]

8. Kfir-Erenfeld, S.; Yefenof, E. Non-genomic events determining the sensitivity of hemopoietic malignancies to glucocorticoid-induced apoptosis. Cancer Immunol. Immunother. 2014, 63, 37-43. [CrossRef] [PubMed]

9. Sionov, R.V.; Spokoini, R.; Kfir, R.S.; Cohen, O.; Yefenof, E. Mechanisms regulating the susceptibility of hematopoietic malignancies to glucocorticoid-induced apoptosis. Adv. Cancer Res. 2008, 101, 127-248. [PubMed]

10. Photiou, L.; van der Weyden, C.; McCormack, C.; Miles Prince, H. Systemic treatment options for advanced-stage mycosis fungoides and sézary syndrome. Curr. Oncol. Rep. 2018, 20, 32. [CrossRef] [PubMed]

11. Platzbecker, U.; Avvisati, G.; Cicconi, L.; Thiede, C.; Paoloni, F.; Vignetti, M.; Ferrara, F.; Divona, M.; Albano, F.; Efficace, F.; et al. Improved Outcomes With Retinoic Acid and Arsenic Trioxide Compared With Retinoic Acid and Chemotherapy in Non-High-Risk Acute Promyelocytic Leukemia: Final Results of the Randomized Italian-German APL0406 Trial. J. Clin. Oncol. 2017, 35, 605-612. [CrossRef] [PubMed]

12. Hart, C.; Vogelhuber, M.; Wolff, D.; Klobuch, S.; Ghibelli, L.; Foell, J.; Corbacioglu, S.; Rehe, K.; Haegeman, G.; Thomas, S.; et al. Anakoinosis: Communicative Reprogramming of Tumor Systems-for Rescuing from Chemorefractory Neoplasia. Cancer Microenviron. 2015, 8, 75-92. [CrossRef] [PubMed]

13. Reichle, A.; Hildebrandt, G.C. Principles of modular tumor therapy. Cancer Microenviron. 2009, 2, 227-237. [CrossRef] [PubMed] 
14. Bradner, J.E.; Hnisz, D.; Young, R.A. Transcriptional Addiction in Cancer. Cell 2017, 168, 629-643. [CrossRef] [PubMed]

15. Vallée, A.; Lecarpentier, Y. Crosstalk Between Peroxisome Proliferator-Activated Receptor $\gamma$ and the Canonical WNT / $\beta$-Catenin Pathway in Chronic Inflammation and Oxidative Stress During Carcinogenesis. Front. Immunol. 2018, 9, 745. [CrossRef] [PubMed]

16. Michalik, L.; Desvergne, B.; Wahli, W. Peroxisome-proliferator-activated receptors and cancers: Complex stories. Nat. Rev. Cancer 2004, 4, 61-70. [CrossRef] [PubMed]

17. Kersten, S.; Desvergne, B.; Wahli, W. Roles of PPARs in health and disease. Nature 2000, 405, 421-424. [CrossRef] [PubMed]

18. Reichle, A. (Ed.) From Molecular to Modular Tumor Therapy; Springer: Dordrecht, The Netherlands, 2010.

19. Tan, C.K.; Zhuang, Y.; Wahli, W. Synthetic and natural Peroxisome Proliferator-Activated Receptor (PPAR) agonists as candidates for the therapy of the metabolic syndrome. Exp. Opin. Ther. Targets 2017, 21, 333-348. [CrossRef] [PubMed]

20. Bosscher, K. Selective Glucocorticoid Receptor modulators. J. Steroid Biochem. Mol. Biol. 2010, 120, 96-104. [CrossRef] [PubMed]

21. Dasgupta, S.; Lonard, D.M.; O'Malley, B.W. Nuclear receptor coactivators: Master regulators of human health and disease. Ann. Rev. Med. 2014, 65, 279-292. [CrossRef] [PubMed]

22. Akbiyik, F.; Ray, D.M.; Gettings, K.F.; Blumberg, N.; Francis, C.W.; Phipps, R.P. Human bone marrow megakaryocytes and platelets express PPAR $\gamma$, and PPAR $\gamma$ agonists blunt platelet release of CD40 ligand and thromboxanes. Blood 2004, 104, 1361-1368. [CrossRef] [PubMed]

23. Lin, C.; Yang, L.; Tanasa, B.; Hutt, K.; Ju, B.-g.; Ohgi, K.; Zhang, J.; Rose, D.W.; Fu, X.-D.; Glass, C.K.; et al. Nuclear receptor-induced chromosomal proximity and DNA breaks underlie specific translocations in cancer. Cell 2009, 139, 1069-1083. [CrossRef] [PubMed]

24. Koeffler, H.P. Peroxisome proliferator-activated receptor $\gamma$ and cancers. Clin. Cancer Res. 2003, 9, 1-9. [PubMed]

25. Danielian, P.S.; White, R.; Lees, J.A.; Parker, M.G. Identification of a conserved region required for hormone dependent transcriptional activation by steroid hormone receptors. EMBO J. 1992, 11, 1025-1033. [CrossRef] [PubMed]

26. Sorrentino, G.; Ruggeri, N.; Zannini, A.; Ingallina, E.; Bertolio, R.; Marotta, C.; Neri, C.; Cappuzzello, E.; Forcato, M.; Rosato, A.; et al. Glucocorticoid receptor signalling activates YAP in breast cancer. Nat. Commun. 2017, 8, 14073. [CrossRef] [PubMed]

27. Katoh, M.; Katoh, M. WNT signaling pathway and stem cell signaling network. Clin. Cancer Res. 2007, 13, 4042-4045. [CrossRef] [PubMed]

28. Michael, M.S.; Badr, M.Z.; Badawi, A.F. Inhibition of cyclooxygenase-2 and activation of peroxisome proliferator-activated receptor- $\gamma$ synergistically induces apoptosis and inhibits growth of human breast cancer cells. Int. J. Mol. Med. 2003, 11, 733-736. [CrossRef] [PubMed]

29. Lehmann, J.M.; Lenhard, J.M.; Oliver, B.B.; Ringold, G.M.; Kliewer, S.A. Peroxisome proliferator-activated receptors $\alpha$ and $\gamma$ are activated by indomethacin and other non-steroidal anti-inflammatory drugs. J. Biol. Chem. 1997, 272, 3406-3410. [CrossRef] [PubMed]

30. Gelman, L.; Fruchart, J.C.; Auwerx, J. An update on the mechanisms of action of the peroxisome proliferator-activated receptors (PPARs) and their roles in inflammation and cancer. Cell. Mol. life Sci. 1999, 55, 932-943. [CrossRef] [PubMed]

31. Subbaramaiah, K.; Lin, D.T.; Hart, J.C.; Dannenberg, A.J. Peroxisome proliferator-activated receptor $\gamma$ ligands suppress the transcriptional activation of cyclooxygenase-2. Evidence for involvement of activator protein-1 and CREB-binding protein/p300. J. Biol. Chem. 2001, 276, 12440-12448. [CrossRef] [PubMed]

32. Badawi, A.F.; Badr, M.Z. Expression of cyclooxygenase- 2 and peroxisome proliferator-activated receptor- $\gamma$ and levels of prostaglandin E2 and 15-deoxy-delta12,14-prostaglandin J2 in human breast cancer and metastasis. Int. J. Cancer 2003, 103, 84-90. [CrossRef] [PubMed]

33. Lee, C.J.; Han, J.S.; Seo, C.Y.; Park, T.H.; Kwon, H.C.; Jeong, J.S.; Kim, I.H.; Yun, J.; Bae, Y.S.; Kwak, J.Y.; et al. Pioglitazone, a synthetic ligand for PPAR $\gamma$, induces apoptosis in RB-deficient human colorectal cancer cells. Apoptosis 2006, 11, 401-411. [CrossRef] [PubMed] 
34. Clay, C.E.; Namen, A.M.; Atsumi, G.; Willingham, M.C.; High, K.P.; Kute, T.E.; Trimboli, A.J.; Fonteh, A.N.; Dawson, P.A.; Chilton, F.H. Influence of J series prostaglandins on apoptosis and tumorigenesis of breast cancer cells. Carcinogenesis 1999, 20, 1905-1911. [CrossRef] [PubMed]

35. Nagahara, T.; Okano, J.; Murawaki, Y. Mechanisms of anti-proliferative effect of JTE-522, a selective cyclooxygenase-2 inhibitor, on human liver cancer cells. Oncol. Rep. 2007, 18, 1281-1290. [CrossRef] [PubMed]

36. Meyer, S.; Vogt, T.; Landthaler, M.; Berand, A.; Reichle, A.; Bataille, F.; Marx, A.H.; Menz, A.; Hartmann, A.; Kunz-Schughart, L.A.; et al. Cyclooxygenase 2 (COX2) and peroxisome proliferator-activated receptor $\gamma$ (PPARG) are stage-dependent prognostic markers of malignant melanoma. PPAR Res. 2009, 2009, 848645. [PubMed]

37. Bundscherer, A.; Reichle, A.; Hafner, C.; Meyer, S.; Vogt, T. Targeting the tumor stroma with peroxisome proliferator activated receptor (PPAR) agonists. ACAMC 2009, 9, 816-821. [CrossRef]

38. Knower, K.C.; Chand, A.L.; Eriksson, N.; Takagi, K.; Miki, Y.; Sasano, H.; Visvader, J.E.; Lindeman, G.J.; Funder, J.W.; Fuller, P.J.; et al. Distinct nuclear receptor expression in stroma adjacent to breast tumors. Breast Cancer Res. Treat. 2013, 142, 211-223. [CrossRef] [PubMed]

39. Basu-Roy, U.; Han, E.; Rattanakorn, K.; Gadi, A.; Verma, N.; Maurizi, G.; Gunaratne, P.H.; Coarfa, C.; Kennedy, O.D.; Garabedian, M.J.; et al. PPAR $\gamma$ agonists promote differentiation of cancer stem cells by restraining YAP transcriptional activity. Oncotarget 2016, 7, 60954-60970. [CrossRef] [PubMed]

40. Mulholland, D.J.; Dedhar, S.; Coetzee, G.A.; Nelson, C.C. Interaction of nuclear receptors with the Wnt/ $\beta$-catenin/Tcf signaling axis: Wnt you like to know? Endocr. Rev. 2005, 26, 898-915. [CrossRef] [PubMed]

41. Vallée, A.; Lecarpentier, Y.; Guillevin, R.; Vallée, J.-N. Opposite Interplay Between the Canonical WNT/ $\beta$-Catenin Pathway and PPAR $\gamma$ : A Potential Therapeutic Target in Gliomas. Neurosci. Bull. 2018, 34, 573-588. [CrossRef] [PubMed]

42. Maniati, E.; Bossard, M.; Cook, N.; Candido, J.B.; Emami-Shahri, N.; Nedospasov, S.A.; Balkwill, F.R.; Tuveson, D.A.; Hagemann, T. Crosstalk between the canonical NF- $k B$ and Notch signaling pathways inhibits Ppar $\gamma$ expression and promotes pancreatic cancer progression in mice. J. Clin. Investig. 2011, 121, 4685-4699. [CrossRef] [PubMed]

43. Hong, O.-Y.; Youn, H.J.; Jang, H.-Y.; Jung, S.H.; Noh, E.-M.; Chae, H.S.; Jeong, Y.-J.; Kim, W.; Kim, C.-H.; Kim, J.-S. Troglitazone inhibits matrix metalloproteinase-9 expression and invasion of breast cancer cell through a peroxisome proliferator-activated receptor $\gamma$-dependent mechanism. J. Breast Cancer 2018, 21, 28-36. [CrossRef] [PubMed]

44. Ge, Y.; Domschke, C.; Stoiber, N.; Schott, S.; Heil, J.; Rom, J.; Blumenstein, M.; Thum, J.; Sohn, C.; Schneeweiss, A.; et al. Metronomic cyclophosphamide treatment in metastasized breast cancer patients: Immunological effects and clinical outcome. Cancer Immunol. Immunother. 2012, 61, 353-362. [CrossRef] [PubMed]

45. Tontonoz, P.; Singer, S.; Forman, B.M.; Sarraf, P.; Fletcher, J.A.; Fletcher, C.D.; Brun, R.P.; Mueller, E.; Altiok, S.; Oppenheim, H.; et al. Terminal differentiation of human liposarcoma cells induced by ligands for peroxisome proliferator-activated receptor $\gamma$ and the retinoid X receptor. Proc. Natl. Acad. Sci. USA 1997, 94, 237-241. [CrossRef] [PubMed]

46. Demetri, G.D.; Fletcher, C.D.M.; Mueller, E.; Sarraf, P.; Naujoks, R.; Campbell, N.; Spiegelman, B.M.; Singer, S. Induction of solid tumor differentiation by the peroxisome proliferator-activated receptor- $\gamma$ ligand troglitazone in patients with liposarcoma. Proc. Natl. Acad. Sci. USA 1999, 96, 3951-3956. [CrossRef] [PubMed]

47. Debrock, G.; Vanhentenrijk, V.; Sciot, R.; Debiec-Rychter, M.; Oyen, R.; van Oosterom, A. A phase II trial with rosiglitazone in liposarcoma patients. Br. J. Cancer 2003, 89, 1409-1412. [CrossRef] [PubMed]

48. Coras, B.; Hafner, C.; Reichle, A.; Hohenleutner, U.; Szeimies, R.-M.; Landthaler, M.; Vogt, T. Antiangiogenic therapy with pioglitazone, rofecoxib, and trofosfamide in a patient with endemic kaposi sarcoma. Arch. Dermatol. 2004, 140, 1504-1507. [CrossRef] [PubMed]

49. Vogt, T.; Hafner, C.; Bross, K.; Bataille, F.; Jauch, K.-W.; Berand, A.; Landthaler, M.; Andreesen, R.; Reichle, A. Antiangiogenetic therapy with pioglitazone, rofecoxib, and metronomic trofosfamide in patients with advanced malignant vascular tumors. Cancer 2003, 98, 2251-2256. [CrossRef] [PubMed] 
50. Burstein, H.J.; Demetri, G.D.; Mueller, E.; Sarraf, P.; Spiegelman, B.M.; Winer, E.P. Use of the peroxisome proliferator-activated receptor (PPAR) $\gamma$ ligand troglitazone as treatment for refractory breast cancer: A phase II study. Breast Cancer Res. Treat. 2003, 79, 391-397. [CrossRef] [PubMed]

51. Hart, C.; Vogelhuber, M.; Hafner, C.; Landthaler, M.; Berneburg, M.; Haferkamp, S.; Herr, W.; Reichle, A. Biomodulatory metronomic therapy in stage IV melanoma is well-tolerated and may induce prolonged progression-free survival, a phase I trial. J. Eur. Acad. Dermatol. Venereol. 2016, 30, e119-e121. [CrossRef] [PubMed]

52. Reichle, A.; Vogt, T.; Coras, B.; Terheyden, P.; Neuber, K.; Trefzer, U.; Schultz, E.; Berand, A.; Bröcker, E.B.; Landthaler, M.; et al. Targeted combined anti-inflammatory and angiostatic therapy in advanced melanoma: A randomized phase II trial. Melanoma Res. 2007, 17, 360-364. [CrossRef] [PubMed]

53. Kulke, M.H.; Demetri, G.D.; Sharpless, N.E.; Ryan, D.P.; Shivdasani, R.; Clark, J.S.; Spiegelman, B.M.; Kim, H.; Mayer, R.J.; Fuchs, C.S. A phase II study of troglitazone, an activator of the PPAR $\gamma$ receptor, in patients with chemotherapy-resistant metastatic colorectal cancer. Cancer J. 2002, 8, 395-399. [CrossRef] [PubMed]

54. Reichle, A.; Grassinger, J.; Bross, K.; Wilke, J.; Suedhoff, T.; Walter, B.; Wieland, W.-F.; Berand, A.; Andreesen, R. C-reactive protein in patients with metastatic clear cell renal carcinoma: An important biomarker for tumor-associated inflammation. Biomark. Insights 2007, 1, 87-98. [CrossRef] [PubMed]

55. Mueller, E.; Smith, M.; Sarraf, P.; Kroll, T.; Aiyer, A.; Kaufman, D.S.; Oh, W.; Demetri, G.; Figg, W.D.; Zhou, X.P.; et al. Effects of ligand activation of peroxisome proliferator-activated receptor $\gamma$ in human prostate cancer. Proc. Natl. Acad. Sci. USA 2000, 97, 10990-10995. [CrossRef] [PubMed]

56. Vogelhuber, M.; Feyerabend, S.; Stenzl, A.; Suedhoff, T.; Schulze, M.; Huebner, J.; Oberneder, R.; Wieland, W.; Mueller, S.; Eichhorn, F.; et al. Biomodulatory treatment of patients with castration-resistant prostate cancer: A phase II study of imatinib with pioglitazone, etoricoxib, dexamethasone and low-dose treosulfan. Cancer Microenviron. 2015, 8, 33-41. [CrossRef] [PubMed]

57. Walter, B.; Rogenhofer, S.; Vogelhuber, M.; Berand, A.; Wieland, W.F.; Andreesen, R.; Reichle, A. Modular therapy approach in metastatic castration-refractory prostate cancer. World J. Urol. 2010, 28, 745-750. [CrossRef] [PubMed]

58. Vogt, T.; Coras, B.; Hafner, C.; Landthaler, M.; Reichle, A. Antiangiogenic therapy in metastatic prostate carcinoma complicated by cutaneous lupus erythematodes. Lancet Oncol. 2006, 7, 695-697. [CrossRef]

59. Smith, M.R.; Manola, J.; Kaufman, D.S.; George, D.; Oh, W.K.; Mueller, E.; Slovin, S.; Spiegelman, B.; Small, E.; Kantoff, P.W. Rosiglitazone versus placebo for men with prostate carcinoma and a rising serum prostate-specific antigen level after radical prostatectomy and/or radiation therapy. Cancer 2004, 101, 1569-1574. [CrossRef] [PubMed]

60. Reichle, A.; Lugner, A.; Ott, C.; Klebl, F.; Vogelhuber, M.; Berand, A.; Andreesen, R. Control of cancer-associated inflammation and survival: Results from a prospective randomized phase II trial in gastric cancer. J. Clin. Oncol. 2009, 27, e15584.

61. Hau, P.; Kunz-Schughart, L.; Bogdahn, U.; Baumgart, U.; Hirschmann, B.; Weimann, E.; Muhleisen, H.; Ruemmele, P.; Steinbrecher, A.; Reichle, A. Low-dose chemotherapy in combination with COX-2 inhibitors and PPAR- $\gamma$ agonists in recurrent high-grade gliomas-A phase II study. Oncology 2007, 73, 21-25. [CrossRef] [PubMed]

62. Reichle, A.; Hart, C.; Grube, M.; Andreesen, R. Anti-inflammatory, immuno-modulatory and angiostatic treatment as third-line therapy for multiple myeloma (MM) - A combined treatment setting of lenalidomide with pioglitazone, dexamethasone and low-dose treosulfan (phase I/II). Blood 2012, 120, 5029.

63. Heudobler, D.; Rehe, K.; Foell, J.; Corbacioglu, S.; Hildebrandt, G.; Herr, W.; Reichle, A.; Vogelhuber, M. Biomodulatory metronomic therapy shows remarkable activity in chemorefractory multi-system langerhans cell histiocytosis. Blood 2016, 128, 4254.

64. Reichle, A.; Vogt, T.; Kunz-Schughart, L.; Bretschneider, T.; Bachthaler, M.; Bross, K.; Freund, S.; Andreesen, R. Anti-inflammatory and angiostatic therapy in chemorefractory multisystem Langerhans' cell histiocytosis of adults. Br. J. Haematol. 2005, 128, 730-732. [CrossRef] [PubMed]

65. Ugocsai, P.; Wolff, D.; Menhart, K.; Hellwig, D.; Holler, E.; Herr, W.; Reichle, A. Biomodulatory metronomic therapy induces PET-negative remission in chemo- and brentuximab-refractory Hodgkin lymphoma. Br. J. Haematol. 2016, 172, 290-293. [CrossRef] [PubMed] 
66. Prost, S.; Relouzat, F.; Spentchian, M.; Ouzegdouh, Y.; Saliba, J.; Massonnet, G.; Beressi, J.-P.; Verhoeyen, E.; Raggueneau, V.; Maneglier, B.; et al. Erosion of the chronic myeloid leukaemia stem cell pool by PPAR $\gamma$ agonists. Nature 2015, 525, 380-383. [CrossRef] [PubMed]

67. Thomas, S.; Schelker, R.; Klobuch, S.; Zaiss, S.; Troppmann, M.; Rehli, M.; Haferlach, T.; Herr, W.; Reichle, A. Biomodulatory therapy induces complete molecular remission in chemorefractory acute myeloid leukemia. Haematologica 2015, 100, 4-6. [CrossRef] [PubMed]

68. Heudobler, D.; Klobuch, S.; Thomas, S.; Hahn, J.; Herr, W.; Reichle, A. Cutaneous leukemic infiltrates successfully treated with biomodulatory therapy in a rare case of therapy-related high risk MDS/AML. Front. Pharmacol. 2018. [CrossRef]

69. Simkens, L.H.J.; van Tinteren, H.; May, A.; Tije, A.J.; Creemers, G.-J.M.; Loosveld, O.J.L.; Jongh, F.E.; Erdkamp, F.L.G.; van der Torren, A.M.; Tol, J. Maintenance treatment with capecitabine and bevacizumab in metastatic colorectal cancer (CAIRO3): A phase 3 randomised controlled trial of the Dutch Colorectal Cancer Group. Lancet 2015, 385, 1843-1852. [CrossRef]

70. Pramanik, R.; Agarwala, S.; Gupta, Y.K.; Thulkar, S.; Vishnubhatla, S.; Batra, A.; Dhawan, D.; Bakhshi, S. Metronomic Chemotherapy vs Best Supportive Care in Progressive Pediatric Solid Malignant Tumors: A Randomized Clinical Trial. JAMA Oncol. 2017, 3, 1222-1227. [CrossRef] [PubMed]

71. Rochlitz, C.; Bigler, M.; Moos, R.; Bernhard, J.; Matter-Walstra, K.; Wicki, A.; Zaman, K.; Anchisi, S.; Küng, M.; $\mathrm{Na}$, K.-J.; et al. SAKK 24/09: Safety and tolerability of bevacizumab plus paclitaxel vs. bevacizumab plus metronomic cyclophosphamide and capecitabine as first-line therapy in patients with HER2-negative advanced stage breast cancer-A multicenter, randomized phase III trial. BMC Cancer 2016, 16, 780. [CrossRef] [PubMed]

72. Kummar, S.; Wade, J.L.; Oza, A.M.; Sullivan, D.; Chen, A.P.; Gandara, D.R.; Ji, J.; Kinders, R.J.; Wang, L.; Allen, D.; et al. Randomized phase II trial of cyclophosphamide and the oral poly (ADP-ribose) polymerase inhibitor veliparib in patients with recurrent, advanced triple-negative breast cancer. Investig. New Drugs 2016, 34, 355-363. [CrossRef] [PubMed]

73. Bottini, A.; Generali, D.; Brizzi, M.P.; Fox, S.B.; Bersiga, A.; Bonardi, S.; Allevi, G.; Aguggini, S.; Bodini, G.; Milani, M.; et al. Randomized phase II trial of letrozole and letrozole plus low-dose metronomic oral cyclophosphamide as primary systemic treatment in elderly breast cancer patients. J. Clin. Oncol. 2006, 24, 3623-3628. [CrossRef] [PubMed]

74. Clarke, J.L.; Iwamoto, F.M.; Sul, J.; Panageas, K.; Lassman, A.B.; DeAngelis, L.M.; Hormigo, A.; Nolan, C.P.; Gavrilovic, I.; Karimi, S.; et al. Randomized phase II trial of chemoradiotherapy followed by either dose-dense or metronomic temozolomide for newly diagnosed glioblastoma. J. Clin. Oncol. 2009, 27, 3861-3867. [CrossRef] [PubMed]

75. Senerchia, A.A.; Macedo, C.R.; Ferman, S.; Scopinaro, M.; Cacciavillano, W.; Boldrini, E.; Lins de Moraes, V.L.; Rey, G.; Oliveira, C.T.; Castillo, L.; et al. Results of a randomized, prospective clinical trial evaluating metronomic chemotherapy in nonmetastatic patients with high-grade, operable osteosarcomas of the extremities: A report from the Latin American Group of Osteosarcoma Treatment. Cancer 2017, 123, 1003-1010. [CrossRef] [PubMed]

76. Konopleva, M.; Andreeff, M. Role of peroxisome proliferator-activated receptor- $\gamma$ in hematologic malignancies. Curr. Opin. Hematol. 2002, 9, 294-302. [CrossRef] [PubMed]

77. Elrod, H.A.; Sun, S.-Y. PPAR $\gamma$ and Apoptosis in Cancer. PPAR Res. 2008, 2008, 704165. [CrossRef] [PubMed]

78. Nemenoff, R.A.; Winn, R.A. Role of nuclear receptors in lung tumourigenesis. Eur. J. Cancer 2005, 41, 2561-2568. [CrossRef] [PubMed]

79. Rumi, M.A.K.; Ishihara, S.; Kazumori, H.; Kadowaki, Y.; Kinoshita, Y. Can PPAR $\gamma$ ligands be used in cancer therapy? Curr. Med. Chem. 2004, 4, 465-477.

80. Schmidt, M.V.; Brüne, B.; Knethen, A. The nuclear hormone receptor PPAR $\gamma$ as a therapeutic target in major diseases. Sci. World J. 2010, 10, 2181-2197. [CrossRef] [PubMed]

81. Youssef, J.; Badr, M. Peroxisome proliferator-activated receptors and cancer: Challenges and opportunities. Br. J. Haematol. 2011, 164, 68-82. [CrossRef] [PubMed]

82. Skelhorne-Gross, G.; Nicol, C.J.B. The Key to Unlocking the Chemotherapeutic Potential of PPAR $\gamma$ Ligands: Having the Right Combination. PPAR Res. 2012, 2012, 946943. [CrossRef] [PubMed] 
83. Polvani, S.; Tarocchi, M.; Tempesti, S.; Bencini, L.; Galli, A. Peroxisome proliferator activated receptors at the crossroad of obesity, diabetes, and pancreatic cancer. World J. Gastroenterol. 2016, 22, 2441-2459. [CrossRef] [PubMed]

84. Vella, V.; Nicolosi, M.L.; Giuliano, S.; Bellomo, M.; Belfiore, A.; Malaguarnera, R. PPAR- $\gamma$ Agonists As Antineoplastic Agents in Cancers with Dysregulated IGF Axis. Front. Endocrinol. 2017, 8, 31. [CrossRef] [PubMed]

85. Querfeld, C.; Nagelli, L.V.; Rosen, S.T.; Kuzel, T.M.; Guitart, J. Bexarotene in the treatment of cutaneous T-cell lymphoma. Exp. Opin. Pharmacother. 2006, 7, 907-915. [CrossRef] [PubMed]

86. Fröhlich, E.; Wahl, R. Chemotherapy and chemoprevention by thiazolidinediones. BioMed Res. Int. 2015, 2015, 845340. [CrossRef] [PubMed]

87. Higurashi, T.; Hosono, K.; Takahashi, H.; Komiya, Y.; Umezawa, S.; Sakai, E.; Uchiyama, T.; Taniguchi, L.; Hata, Y.; Uchiyama, S.; et al. Metformin for chemoprevention of metachronous colorectal adenoma or polyps in post-polypectomy patients without diabetes: A multicentre double-blind, placebo-controlled, randomised phase 3 trial. Lancet Oncol. 2016, 17, 475-483. [CrossRef]

88. Coyle, C.; Cafferty, F.H.; Vale, C.; Langley, R.E. Metformin as an adjuvant treatment for cancer: A systematic review and meta-analysis. Ann. Oncol. 2016, 27, 2184-2195. [CrossRef] [PubMed]

89. Di, W.; Di, H.; Chen, H.; Shi, G.; Fetahu, I.S.; Wu, F.; Rabidou, K.; Fang, R.; Tan, L.; Xu, S.; et al. Glucose-regulated phosphorylation of TET2 by AMPK reveals a pathway linking diabetes to cancer. Nature 2018, 559, 637-641. [CrossRef] [PubMed]

90. Di Masi, A.; Leboffe, L.; Marinis, E.; Pagano, F.; Cicconi, L.; Rochette-Egly, C.; Lo-Coco, F.; Ascenzi, P.; Nervi, C. Retinoic acid receptors: From molecular mechanisms to cancer therapy. Mol. Aspects Med. 2015, 41, 1-115. [CrossRef] [PubMed]

91. Mitchell, C.D.; Richards, S.M.; Kinsey, S.E.; Lilleyman, J.; Vora, A.; Eden, T.O.B. Benefit of dexamethasone compared with prednisolone for childhood acute lymphoblastic leukaemia: Results of the UK Medical Research Council ALL97 randomized trial. Br. J. Haematol. 2005, 129, 734-745. [CrossRef] [PubMed]

92. McDermott, D.F.; Regan, M.M.; Clark, J.I.; Flaherty, L.E.; Weiss, G.R.; Logan, T.F.; Kirkwood, J.M.; Gordon, M.S.; Sosman, J.A.; Ernstoff, M.S.; et al. Randomized phase III trial of high-dose interleukin-2 versus subcutaneous interleukin-2 and interferon in patients with metastatic renal cell carcinoma. J. Clin. Oncol. 2005, 23, 133-141. [CrossRef] [PubMed]

93. Brown, S.; Pineda, C.M.; Xin, T.; Boucher, J.; Suozzi, K.C.; Park, S.; Matte-Martone, C.; Gonzalez, D.G.; Rytlewski, J.; Beronja, S.; et al. Correction of aberrant growth preserves tissue homeostasis. Nature 2017, 548, 334-337. [CrossRef] [PubMed]

94. Tang, T.C.; Man, S.; Xu, P.; Francia, G.; Hashimoto, K.; Emmenegger, U.; Kerbel, R.S. Development of a resistance-like phenotype to sorafenib by human hepatocellular carcinoma cells is reversible and can be delayed by metronomic UFT chemotherapy. Neoplasia 2010, 12, 928-940. [CrossRef] [PubMed]

95. Cao, L.; Wang, X.; Wang, Q.; Xue, P.; Jiao, X.; Peng, H.; Lu, H.; Zheng, Q.; Chen, X.; Huang, X.; et al. Rosiglitazone sensitizes hepatocellular carcinoma cell lines to 5-fluorouracil antitumor activity through activation of the PPAR $\gamma$ signaling pathway. Acta Pharmacol. Sin. 2009, 30, 1316-1322. [CrossRef] [PubMed]

96. Cao, L.-q.; Chen, X.-1.; Wang, Q.; Huang, X.-h.; Zhen, M.-C.; Zhang, L.-J.; Li, W.; Bi, J. Upregulation of PTEN involved in rosiglitazone-induced apoptosis in human hepatocellular carcinoma cells. Acta Pharmacol. Sin. 2007, 28, 879-887. [CrossRef] [PubMed]

97. Yap, R.; Veliceasa, D.; Emmenegger, U.; Kerbel, R.S.; McKay, L.M.; Henkin, J.; Volpert, O.V. Metronomic low-dose chemotherapy boosts CD95-dependent antiangiogenic effect of the thrombospondin peptide ABT-510: A complementation antiangiogenic strategy. Clin. Cancer Res. 2005, 11, 6678-6685. [CrossRef] [PubMed]

98. Biziota, E.; Briasoulis, E.; Mavroeidis, L.; Marselos, M.; Harris, A.L.; Pappas, P. Cellular and molecular effects of metronomic vinorelbine and 4-O-deacetylvinorelbine on human umbilical vein endothelial cells. Anti-Cancer Drugs 2016, 27, 216-224. [CrossRef] [PubMed]

99. Ogawa, S.; Lozach, J.; Benner, C.; Pascual, G.; Tangirala, R.K.; Westin, S.; Hoffmann, A.; Subramaniam, S.; David, M.; Rosenfeld, M.G.; et al. Molecular determinants of crosstalk between nuclear receptors and toll-like receptors. Cell 2005, 122, 707-721. [CrossRef] [PubMed]

100. Mitsiades, C.S.; Mitsiades, N.; Richardson, P.G.; Treon, S.P.; Anderson, K.C. Novel biologically based therapies for Waldenstrom's macroglobulinemia. Semin. Oncol. 2003, 30, 309-312. [CrossRef] [PubMed] 
101. Hisatake, J.I.; Ikezoe, T.; Carey, M.; Holden, S.; Tomoyasu, S.; Koeffler, H.P. Down-Regulation of prostate-specific antigen expression by ligands for peroxisome proliferator-activated receptor $\gamma$ in human prostate cancer. Cancer Res. 2000, 60, 5494-5498. [PubMed]

102. Narayanan, S.; Srinivas, S.; Feldman, D. Androgen-glucocorticoid interactions in the era of novel prostate cancer therapy. Nat. Rev. Urol. 2016, 13, 47-60. [CrossRef] [PubMed]

103. Mansour, M.; Schwartz, D.; Judd, R.; Akingbemi, B.; Braden, T.; Morrison, E.; Dennis, J.; Bartol, F.; Hazi, A.; Napier, I.; et al. Thiazolidinediones/PPAR $\gamma$ agonists and fatty acid synthase inhibitors as an experimental combination therapy for prostate cancer. Int. J. Oncol. 2011, 38, 537-546. [CrossRef] [PubMed]

104. Papi, A.; Guarnieri, T.; Storci, G.; Santini, D.; Ceccarelli, C.; Taffurelli, M.; Carolis, S.; Avenia, N.; Sanguinetti, A.; Sidoni, A.; et al. Nuclear receptors agonists exert opposing effects on the inflammation dependent survival of breast cancer stem cells. Cell Death Differ. 2012, 19, 1208-1219. [CrossRef] [PubMed]

105. Papi, A.; Rocchi, P.; Ferreri, A.M.; Orlandi, M. RXR $\gamma$ and PPAR $\gamma$ ligands in combination to inhibit proliferation and invasiveness in colon cancer cells. Cancer Lett. 2010, 297, 65-74. [CrossRef] [PubMed]

106. Papi, A.; Storci, G.; Guarnieri, T.; Carolis, S.; Bertoni, S.; Avenia, N.; Sanguinetti, A.; Sidoni, A.; Santini, D.; Ceccarelli, C.; et al. Peroxisome proliferator activated receptor- $\alpha /$ hypoxia inducible factor- $1 \alpha$ interplay sustains carbonic anhydrase IX and apoliprotein E expression in breast cancer stem cells. PLoS ONE 2013, 8, e54968. [CrossRef] [PubMed]

107. Papi, A.; Tatenhorst, L.; Terwel, D.; Hermes, M.; Kummer, M.P.; Orlandi, M.; Heneka, M.T. PPAR $\gamma$ and RXR $\gamma$ ligands act synergistically as potent antineoplastic agents in vitro and in vivo glioma models. J. Neurochem. 2009, 109, 1779-1790. [CrossRef] [PubMed]

108. Konopleva, M.; Elstner, E.; McQueen, T.J.; Tsao, T.; Sudarikov, A.; Hu, W.; Schober, W.D.; Wang, R.-Y.; Chism, D.; Kornblau, S.M.; et al. Peroxisome proliferator-activated receptor $\gamma$ and retinoid $X$ receptor ligands are potent inducers of differentiation and apoptosis in leukemias. Mol. Cancer Ther. 2004, 3, 1249-1262. [PubMed]

109. Thiounn, N.; Pages, F.; Flam, T.; Tartour, E.; Mosseri, V.; Zerbib, M.; Beuzeboc, P.; Deneux, L.; Fridman, W.H.; Debré, B. IL-6 is a survival prognostic factor in renal cell carcinoma. Immunol. Lett. 1997, 58, 121-124. [CrossRef]

110. Tilg, H.; Vogel, W.; Dinarello, C.A. Interferon- $\alpha$ induces circulating tumor necrosis factor receptor p55 in humans. Blood 1995, 85, 433-435. [CrossRef]

111. Jabs, W.J.; Busse, M.; Krüger, S.; Jocham, D.; Steinhoff, J.; Doehn, C. Expression of C-reactive protein by renal cell carcinomas and unaffected surrounding renal tissue. Kidney Int. 2005, 68, 2103-2110. [CrossRef] [PubMed]

112. Buer, J.; Probst, M.; Ganser, A.; Atzpodien, J. Response to 13-cis-retinoic acid plus interferon alfa-2a in two patients with therapy-refractory advanced renal cell carcinoma. J. Clin. Oncol. 1995, 13, 2679-2680. [CrossRef] [PubMed]

113. Aviles, A.; Neri, N.; Fernandez-Diez, J.; Silva, L.; Nambo, M.-J. Interferon and low doses of methotrexate versus interferon and retinoids in the treatment of refractory/relapsed cutaneous T-cell lymphoma. Hematology 2015, 20, 538-542. [CrossRef] [PubMed]

114. Finch, E.R.; Tukaramrao, D.B.; Goodfield, L.L.; Quickel, M.D.; Paulson, R.F.; Prabhu, K.S. Activation of PPAR $\gamma$ by endogenous prostaglandin J2 mediates the antileukemic effect of selenium in murine leukemia. Blood 2017, 129, 1802-1810. [CrossRef] [PubMed]

115. Chu, T.-H.; Chan, H.-H.; Kuo, H.-M.; Liu, L.-F.; Hu, T.-H.; Sun, C.-K.; Kung, M.-L.; Lin, S.-W.; Wang, E.-M.; Ma, Y.-L.; et al. Celecoxib suppresses hepatoma stemness and progression by up-regulating PTEN. Oncotarget 2014, 5, 1475-1490. [CrossRef] [PubMed]

116. Xu, L.; Han, C.; Lim, K.; Wu, T. Cross-talk between peroxisome proliferator-activated receptor delta and cytosolic phospholipase $\mathrm{A}(2) \alpha$ /cyclooxygenase-2/prostaglandin $\mathrm{E}(2)$ signaling pathways in human hepatocellular carcinoma cells. Cancer Res. 2006, 66, 11859-11868. [CrossRef] [PubMed]

117. Zheng, Z.; Zhou, L.; Gao, S.; Yang, Z.; Yao, J.; Zheng, S. Prognostic role of C-reactive protein in hepatocellular carcinoma: A systematic review and meta-analysis. Int. J. Med. Sci. 2013, 10, 653-664. [CrossRef] [PubMed]

118. Mustafa, A.; Kruger, W.D. Suppression of tumor formation by a cyclooxygenase-2 inhibitor and a peroxisome proliferator-activated receptor $\gamma$ agonist in an in vivo mouse model of spontaneous breast cancer. Clin. Cancer Res. 2008, 14, 4935-4942. [CrossRef] [PubMed] 
119. Liu, D.; Mai, K.; Zhang, Y.; Xu, W.; Ai, Q. Tumour necrosis factor- $\alpha$ inhibits hepatic lipid deposition through GSK-3 $\beta$ / $\beta$-catenin signaling in juvenile turbot (Scophthalmus maximus L.). Gen. Comp. Endocrinol. 2015, 228, 1-8. [CrossRef] [PubMed]

120. DeCicco, K.L.; Tanaka, T.; Andreola, F.; Luca, L.M. The effect of thalidomide on non-small cell lung cancer (NSCLC) cell lines: Possible involvement in the PPAR $\gamma$ pathway. Carcinogenesis 2004, 25, 1805-1812. [CrossRef] [PubMed]

121. Rousselot, P.; Prost, S.; Guilhot, J.; Roy, L.; Etienne, G.; Legros, L.; Charbonnier, A.; Coiteux, V.; Cony-Makhoul, P.; Huguet, F.; et al. Pioglitazone together with imatinib in chronic myeloid leukemia: A proof of concept study. Cancer 2017, 123, 1791-1799. [CrossRef] [PubMed]

122. Han, S.; Roman, J. Rosiglitazone suppresses human lung carcinoma cell growth through PPAR $\gamma$-dependent and PPAR $\gamma$-independent signal pathways. Mol. Cancer Ther. 2006, 5, 430-437. [CrossRef] [PubMed]

123. Hafner, C.; Reichle, A.; Vogt, T. New indications for established drugs: Combined tumor-stroma-targeted cancer therapy with PPAR $\gamma$ agonists, COX-2 inhibitors, mTOR antagonists and metronomic chemotherapy. CCDT 2005, 5, 393-419. [CrossRef]

124. Reichle, A. Evolution-adjusted Tumor Pathophysiology; Springer: Dordrecht, The Netherlands, 2013.

125. Muqaku, B.; Eisinger, M.; Meier, S.M.; Tahir, A.; Pukrop, T.; Haferkamp, S.; Slany, A.; Reichle, A.; Gerner, C. Multi-omics Analysis of Serum Samples Demonstrates Reprogramming of Organ Functions Via Systemic Calcium Mobilization and Platelet Activation in Metastatic Melanoma. Mol. Cell. Proteom. 2017, 16, 86-99. [CrossRef] [PubMed]

126. Hanash, S.M.; Pitteri, S.J.; Faca, V.M. Mining the plasma proteome for cancer biomarkers. Nature 2008, 452, 571-579. [CrossRef] [PubMed]

127. Reichle, A. Tumor Systems Need to be Rendered Usable for a New Action-Theoretical Abstraction: The Starting Point for Novel Therapeutic Options. In From Molecular to Modular Tumor Therapy; Reichle, A., Ed.; Springer Netherlands: Dordrecht, The Netherlands, 2010; pp. 9-28.

(C) 2018 by the authors. Licensee MDPI, Basel, Switzerland. This article is an open access article distributed under the terms and conditions of the Creative Commons Attribution (CC BY) license (http:/ / creativecommons.org/licenses/by/4.0/). 